NBER WORKING PAPER SERIES

\title{
SECURITIZATION AND THE DECLINING IMPACT OF BANK FINANCE ON LOAN SUPPLY: EVIDENCE FROM MORTGAGE ACCEPTANCE RATES
}

\author{
Elena Loutskina \\ Philip E. Strahan \\ Working Paper 11983 \\ http://www.nber.org/papers/w11983
NATIONAL BUREAU OF ECONOMIC RESEARCH 1050 Massachusetts Avenue
Cambridge, MA 02138
January 2006

We thank Scott Frame, Jeff Pontiff, Toby Moskowitz, Amir Sufi, and Andrei Zmatchenok for helpful comments on the paper, as well as seminar participants at the Financial Research Association Conference, the Federal Reserve Banks of New York and San Francisco, RPI, the University of Connecticut, and the University of Chicago. The authors also thank the Fondation Banque de France for financial support. The views expressed herein are those of the author(s) and do not necessarily reflect the views of the National Bureau of Economic Research.

(C)2006 by Elena Loutskina and Philip E. Strahan. All rights reserved. Short sections of text, not to exceed two paragraphs, may be quoted without explicit permission provided that full credit, including $\odot$ notice, is given to the source. 
Securitization and the Declining Impact of Bank Finance on Loan Supply: Evidence from Mortgage Acceptance Rates

Elena Loutskina and Philip E. Strahan

NBER Working Paper No. 11983

January 2006

JEL No. G2

\begin{abstract}
$\underline{\text { ABSTRACT }}$
This paper shows that securitization reduces the influence of bank financial condition on loan supply. Low-cost funding and increased balance-sheet liquidity raise bank willingness to approve mortgages that are hard to sell (jumbo mortgages), while having no effect on their willingness to approve mortgages easy to sell (non-jumbos). Thus, the increasing depth of the mortgage secondary market fostered by securitization has reduced the impact of local funding shocks on credit supply. By extension, securitization has weakened the link from bank funding conditions to credit supply in aggregate, thereby mitigating the real effects of monetary policy.
\end{abstract}

Elena Loutskina

Boston College

loutskin@bc.edu

Philip E. Strahan

Carroll School of Management

324B Fulton Hall

Boston College

Chestnut Hill, MA 02467

and NBER

strahan@bc.edu 


\section{INTRODUCTION}

Liquidity transformation - funding illiquid loans with liquid deposits - has been viewed as a fundamental role for banks. Diamond and Dybvig (1983) argue that banks improve welfare by allowing depositors to diversify liquidity risk while investing in high-return, illiquid projects. Securitization has changed the way banks provide liquidity. Today, while real projects remain illiquid, loans have become more liquid because banks often securitize them, thereby replacing deposits with bonds as the primary source of finance. Securitization has grown fastest in mortgage markets because the government-sponsored enterprises (GSEs, i.e. Fannie Mae and Freddie Mac) enhance mortgage-loan liquidity. ${ }^{1}$ By regulation, however, the GSEs only buy mortgages below a given size threshold (the jumbo-loan cutoff). Mortgages below this threshold are more liquid than those above the threshold. This paper shows that bank financial condition, while continuing to affect bank acceptance rates on illiquid loans (jumbos), has no effect on acceptance rates on liquid loans (non-jumbos). Thus, securitization has reduced the impact of bank financial condition on credit supply.

We study mortgages because their liquidity falls sharply around the jumbo-loan cutoff. Such a discrete and exogenous drop in liquidity is difficult to find elsewhere. ${ }^{2}$ To exploit this special feature of the U.S. mortgage market, we first regress the difference in acceptance rates for non-jumbo and jumbo mortgages on bank financial variables and other controls. By comparing relative acceptance rates in our regressions, we 'difference out' unobservable but potentially confounding demand-side factors. The results suggest that this acceptance-rate difference widens at financially constrained banks. 
We further show that while acceptance rates depend on financial condition for jumbo mortgages, acceptance rates for non-jumbos do not vary with the originating bank's financial position because these loans can be easily sold. Thus, loan liquidity seems to eliminate the link from a bank's financial condition to its willingness to supply credit. Mortgage liquidity has increased rapidly over the past 30 years, in part through GSE subsidies. Private-sector financial institutions, however, have also increased loan liquidity in other sectors by securitizing consumer and business loans. Our results therefore extend into these other markets as well.

Figure 1 illustrates our main findings. Panel A compares the aggregate probability of accepting mortgages originated by banks in the top quartile of the funding-cost distribution with those in the bottom quartile of this distribution, where funding costs equal the ratio of a bank's total interest expenses on deposits to total deposits. The figure suggests that banks with high funding costs are reluctant to approve jumbo mortgages, relative to competing banks with low funding costs. On average, the acceptance rate for jumbo mortgages rises from 88.4 percent for high-cost banks to 91.1 percent for low-cost banks. In contrast, the acceptance rate for nonjumbo mortgages barely reflects the originating bank's funding costs at all. ${ }^{3}$ This difference makes sense because banks usually fund accepted jumbo mortgages with deposits. In contrast, banks have the option to sell non-jumbo mortgages to the GSEs, thus avoiding the need to finance them. Panel B reports a similar set of results but focuses on balance-sheet liquidity, defined as the ratio of marketable securities and federal funds sold to assets. Like funding costs, bank liquidity seems to matter less for non-jumbo mortgages (because the bank holds the option to sell the loan) than for jumbos (because the bank must hold the loan).

Funding costs and liquidity may also affect the characteristics of a bank's flow of mortgage applications. For example, loan-application size may be endogenous if funding- 
constrained banks encourage some customers to reduce their borrowing below the jumbo-loan cutoff, either by offering pricing incentives or by threatening to reject the loan. Panel C of Figure 1 tests this idea using marginal loan applications, defined as those within 5 percent of the jumbo-loan cutoff (i.e. between 95 percent and 105 percent of the cutoff). The flow of these marginal applications is related both to bank cost of funds and liquidity. We find that banks with high funding costs or low levels of liquidity receive a larger share of non-jumbo mortgage applications, relative to other banks. Thus, banks better positioned to originate and hold illiquid loans - banks with low cost of deposits and/or a large buffer of liquid assets - supply more of these loans. These banks are more willing to approve jumbo loans, and they receive a greater flow of jumbo-loan applications.

This paper contributes to several strands of research at the intersection of finance and macroeconomics. First, the results suggest that propagation of local business cycles across regions is less pronounced today than in the past, due in part to the developing depth of the mortgage secondary markets. In contrast to the jumbo-loan market, we find no link between a bank's funding or liquidity and its propensity to supply non-jumbo mortgages. Hence, there is no reason to expect that a reduction in local banking capacity will affect most mortgage borrowers. This result matters quantitatively because more than 90 percent of mortgage applications fall below the jumbo-loan cutoff, and because shocks to the local financial system can potentially worsen business downturns. ${ }^{4}$ Integration of the banking system has reduced the effect of these local shocks by allowing capital to flow more freely through the banking system (Ashcraft (2003), Houston, James and Marcus (1997), Morgan, Rime and Strahan (2004), Demyanyk, Ostergaard, and Sorensen (2005)). The growth of mortgage secondary markets is one means by which the financial system has become better integrated over time. Other 
dimensions of integration include expansion of bank branching, cross-state bank consolidation and loan syndication.

Second, consistent with Estrella (2002) and Loutskina (2005), expansion of the secondary market in mortgages has likely dampened the effects of monetary policy on real economic activity. According to the 'bank lending' channel of monetary policy, central banks can slow real activity by raising bank funding costs (e.g. the cost of deposits) and thereby constrain the supply of credit. Our results suggest that there is no link between bank funding costs and credit supplied to the non-jumbo mortgage market. Hence, the lending channel to borrowers in this market has been mitigated by the growth of securitization. ${ }^{5}$ Together with studies on the increasing size and geographical scope of banks, our results thus suggest that the overall potency of monetary policy ought to be reduced relative to earlier times when banks were smaller, less well integrated with other banks, and less able to sell their loans into secondary markets. ${ }^{6}$

Finally, our results shed more light on how non-financial firms' cost of capital depends on their bank's financial condition. ${ }^{7}$ Most of the extant research has tested for effects of monetary policy or bank solvency (capital) shocks on credit supply to bank-dependent firms. ${ }^{8}$ Our results indicate that securitization increases banks' willingness to supply credit to all (even illiquid) sectors, but that high costs of deposits or limited balance-sheet liquidity only affect the supply of illiquid loans (jumbo mortgages here, although the result likely generalizes to other illiquid lending such as small business credit). Like the earlier literature, we also find some evidence that bank solvency affects credit supply -- better capitalized banks receive a larger flow of jumbo applications than less capitalized ones. However, we find no direct link from bank capital to mortgage acceptance rates. 


\section{The SEcondary MARKET For Residential MoRtgages}

\section{A. The Growth of Securitization}

Credit markets have been reshaped by the growth of trading in secondary markets. Banks traditionally originated and held loans on their balance sheets, and thus credit availability depended in part on the cost and availability of funds to banks. Over the past quarter century, however, loan securitization has reshaped lending markets. Securitization typically involves pooling the cash flows from a number of similar assets (e.g. mortgages or credit card accounts) and selling the pool to a separate legal entity known as a special purpose vehicle (SPV). The pooling process results in a diversified portfolio of cash flows, which are used to support payments on debt securities issued by the SPV. Often, the cash flows come with some additional implicit or explicit guarantees from the originating financial institution (or the originator retains the residual or equity tranche in the SPV). Creating this separate SPV isolates the cash-flow generating assets and/or collateral so that securities issued by the SPV are not a general claim against the issuer, just against those assets. Cash flows from the original pool of loans can be further stripped and repackaged based on various characteristics (e.g., the prepayment behavior or payment priority) to enhance their liquidity. ${ }^{9}$

Table 1 illustrates the growing quantitative significance of loan securitization for different types of loans over time. The Table presents the amount of loans outstanding and securitized for six loan categories between 1976 and 2003. Consider, for example, home mortgages: In 1976, the amount of securitized home mortgages was \$28 billion; by the end of 2003 the total amount of securitized home mortgages had grown almost 150 times, reaching $\$ 4.2$ trillion. Over the same period, the amount of home mortgages outstanding grew almost 15 
times, from $\$ 489$ billion to $\$ 7.3$ trillion. Mortgage securitization has grown 10 times as fast as the market itself!

Securitization has also made inroads in the financing of other kinds of loans, albeit less dramatically. In 1976 there was no securitization of commercial mortgages, business loans (commercial and industrial, or C\&I, loans) or consumer loans. By the end of 2003, \$294 billion of commercial mortgages were securitized, \$104 billion worth of C\&I loans were securitized, along with $\$ 658$ billion worth of consumer loans. Figure 2 illustrates these trends graphically.

To understand why securitization of mortgages has taken off so dramatically, one needs to appreciate the role of The Federal National Mortgage Association (Fannie Mae) and the Federal Home Loan Mortgage Corporation (Freddie Mac). These two so-called GovernmentSponsored Enterprises (GSEs) were created by the U.S. Congress to provide stability and liquidity to the market for residential mortgages, and to promote access to mortgage credit and home ownership. Together, they have played the dominant role in fostering the development of the secondary market. Starting in the 1970s, the GSEs began to purchase mortgages from banks, savings institutions and other mortgage originators. As shown by Frame and White (2005), the GSEs have played an increasingly important part in mortgage markets since the early 1980s. For example, by 1990 about 25 percent of the $\$ 2.9$ trillion in outstanding mortgages were either purchased and held or purchased and securitized by the two major GSEs. By 2003, this market share had increased to 47 percent. In other words, today approximately half of all mortgages outstanding were sold to the GSEs after origination (neither Fannie nor Freddie is permitted to originate mortgages themselves).

The GSEs enhance mortgage liquidity either by buying and holding mortgages or by securitizing them. When the GSEs buy mortgages, they bear both credit and interest rate risk. 
When GSEs securitize mortgages, they either buy them and issue mortgage-backed securities (MBS), or they just sell credit protection to the original lender. In the first case, the originating bank retains no stake in the mortgage. In the second case, the bank continues to fund the mortgage and bear the interest rate risk, but obtains the option to sell it off as an MBS. In all cases, the GSEs enhance liquidity. ${ }^{10}$

Most important, the GSE charters limit the size of mortgages that they may purchase or securitize. For example, in 2005 the GSEs could only purchase 'non-jumbo' mortgages, those below $\$ 359,650$. $^{11}$ This cutoff is set annually based on a housing price index. Thus, there is a discrete drop in mortgage liquidity around the jumbo-loan cutoff that is exogenous to financial intermediary decisions.

\section{B. Mortgage Market Segmentation}

The GSE charter limitation conveniently splits the market into a liquid segment (nonjumbo mortgages) and an illiquid segment (jumbo mortgages). How do we know that liquidity really falls at the cutoff? Perhaps the private sector steps in and seamlessly facilitates mortgage securitization in the jumbo market. First, in contrast to jumbos, most non-jumbo mortgages can be sold by the original lender. Second, the GSEs are the only financial institution that will buy individual mortgage loans. Thus, securitization of non-jumbos would be especially costly for small banks without the GSEs. Third, mortgage-backed securities issued by GSEs come with required capital only one-fourth as large as required capital for similar securities (such as jumbomortgage securitizations) issued by private financial institutions under the Basel Capital Accord. Fourth, there is a sharp increase in the frequency of mortgage applications just below the jumboloan cutoff, suggesting that the GSE withdrawal from the jumbo market increases the cost of borrowing. And, more directly, the pricing of mortgages changes around the jumbo-loan cutoff. 
Yields on non-jumbo loans are on the order of 20 basis points lower than the yields on jumbos (e.g. Mckenzie (2002) provides a survey of this literature). If liquidity fell gradually with mortgage size, yields would rise smoothly with size. Instead, yields jump discretely around the jumbo-loan cutoff. Moreover, this yield differential has been relatively stable over time (Figure $3)^{12}$

The jumbo/non-jumbo spread would seem to offer a natural measure of the value of liquidity from the GSEs. Passmore, Sherlund and Burgess (2005) present a model in which this spread rises with bank funding costs, and they use aggregate data to show that this spread increases as the availability of core deposits declines. There are no empirical studies testing how the jumbo/non-jumbo spread varies across lenders because pricing information by lender is not available. Our approach differs from the extant studies of pricing. We focus on the quantity side of the market, where loan applications can be linked to the originating bank, and test how approval rates vary across banks.

We test whether a lender's willingness to approve a jumbo mortgage is affected by its financing conditions. Funding costs should not affect a bank's willingness to make a non-jumbo loan - the loan can be sold to one of the GSEs. Funding costs, however, should affect a bank's willingness to approve jumbo mortgages, since the bank has to hold and hence fund these loans. Similarly, banks with relatively low holdings of liquid assets may be reluctant to approve illiquid jumbo loans because they are difficult to sell, while liquidity concerns should not affect approval rates for non-jumbo mortgages that banks can choose either to sell or to hold. Our main tests focus on the willingness of banks to approve jumbo mortgages, relative to non-jumbo mortgages, as a function of the bank's funding costs and balance-sheet liquidity. 


\section{III.DATA \& SAMPLE SELEction}

\section{A. Sample of Mortgage Applications}

To build our dataset, we start with a comprehensive sample of mortgage applications and originations that have been collected by the Federal Reserve since 1992 under provisions of the Home Mortgage Disclosure Act (HMDA). The sample covers loan applications from 1992 to 2003. HMDA was passed into law by Congress in 1975 and expanded in 1988, with the purpose of informing the public (and the regulators) about whether or not financial institutions adequately serve local credit needs. In addition, regulators use the HMDA data to help identify discriminatory lending. These data are collected by the Federal Reserve under Regulation C, and all regulated financial institutions (e.g. commercial banks, savings institutions, credit unions, and mortgage companies) with assets above $\$ 30$ million must report.

The HMDA data include information on the year of the application (although we know nothing about exactly when during a given year a loan application was made), the dollar amount of the loan, and whether or not the loan was accepted. The dataset also has information on the identity of the lender, which we use to measure the funding and liquidity variables described below. To control for loan risk, we can observe the location of the property, the sex and race of the applicant, and the level of the applicant's income as well as the income-to-loan-size ratio. To control for economic conditions near the property, we know whether or not the property is located within an urban Metropolitan Statistical Area (MSA), the share of the population that is minority in the property's Census Tract, and the median income in that Census Tract. We will control for all of these factors in our models to absorb variation in the risk characteristics of loan applicants. There is unfortunately no information on the market value of the property in the HMDA data. 
Figure 4 plots a histogram of the frequency distribution of mortgage applications from HMDA data over the 1992-2003 period (on the order of 106 million loan applications), as a function of the ratio of loan size to the jumbo-loan cutoff (Panel A). ${ }^{13}$ The figure shows first that most mortgage applications come in below the cutoff value (i.e. most mortgages can be sold easily into the secondary market). Also, we see a sharp spike in the frequency of loan applications just below the cutoff. This spike suggests that the applicant pool itself is endogenously determined, at least in part, by financial conditions. That is, we know that interest rates are higher for jumbo loans, thus some applicants with loan demand "near" the jumbo-loan cutoff may borrow less than they otherwise would to take advantage of the lower rate.

Panel B of Figure 4 reports the average acceptance rate for mortgages, again as a function of the ratio of the loan amount to the jumbo-loan cutoff. As in Panel A, we see a sharp upward spike in the acceptance rate for loans just below the cutoff. The high acceptance rate just below the cutoff suggests that some of the most creditworthy clients borrow less than the cutoff, either to take advantage of lower rates or because the lender would not approve a jumbo loan for these clients. (We address this loan-application size endogeneity in Sections V.B-V.D.) The figure also shows that acceptance rates appear to fall off sharply for very small loans, and the acceptance rate also falls off gradually as loan size increases beyond the jumbo-loan cutoff. The very small loans may be riskier due to the low income and wealth of the applicants, while the very large loans may be riskier due to unusually high demand for credit (Stiglitz and Weiss, 1982).

\section{B. Bank Financial Variables}

To understand how funding costs and liquidity affect the supply of mortgage credit, we collect bank-level data by merging the HMDA loan application data to the Reports of Income 
and Condition for commercial banks (the 'Call Report'). We merge each application to the Call Report from the fourth quarter of the year of the mortgage application using the HMDA bank identification number with call report identification number (RSSD ID) for banks reporting to Federal Reserve Bank, with FDIC certificate ID (item RSSD9050 in Call report) for banks reporting to FDIC, and with OCC ID (item RSSD9055 in Call report) for banks reporting to OCC. The unmatched institutions from HMDA dataset are then matched manually using a bank's name and the zip code of its location.

Using Call Report data, we focus our attention on the cost of deposits to the lender (measured by the ratio of total interest expenses on deposits to total deposits), and on the lender's balance sheet liquidity (the ratio of cash plus securities to total assets). We also control for lender size (log of total assets), leverage (the ratio of capital to assets) and profitability (net income to total assets). Last, we supplement the traditional measure of balance sheet liquidity with an additional measure of loan liquidity, defined following Loutskina (2005) as follows:

LoanLiquidity $_{i t}=\sum_{j=1}^{6}\left(\frac{\text { Economy-wide Securitized Loans of Type } j \text { at Time } t}{\text { Economy-wide Total Loans Outstanding of Type } j \text { at Time } t}\right) *\left(\begin{array}{c}\text { Share of Type } j \text { Loans } \\ \text { in Bank } i \text { Portfolio at Time } t\end{array}\right)$

The economy-wide data on securitization and loans outstanding come from the U.S. Flow of Funds, while the bank-level data come from the Call Report. This index can be thought of as a weighted average of the potential to securitize loans of a given type (based on economy-wide averages - the first term in parentheses), where the weights reflect each bank's individual loan portfolio (the second term in parentheses). Thus, market trends generate time variation in the index (recall Figure 2), whereas differences in bank loan portfolios generate variation across institutions. To construct this measure, we break the loan portfolio into six categories: (i) home 
mortgages; (ii) multifamily residential mortgages, (iii) commercial mortgages, (iv) consumer credit, (v) business loans not secured by real estate (commercial and industrial loans), and (vi) farm mortgages.

The raw HMDA data contain almost 250 million mortgage applications. Of these, we first drop those originated by savings institutions, mortgage bankers, credit unions and other nonbank lenders, leaving about 120 million mortgage applications to financial institutions reporting to FDIC, FRB, and OCC (mostly commercial banks). We then drop mortgages where borrowers are subsidized by the Federal Housing Authority, the Veterans Administration or other government programs, leaving us with about 106 million loan applications. Of these, we keep loans for home purchase only, which reduces the sample to around 35 million (more than half of the loan applications are for mortgage refinancing). We drop cases where a loan application was incomplete or withdrawn - that is, we only keep loan applications where we can determine whether or not the lender approved or denied the application. To be sure our sample is relatively homogeneous (recall Figure 4 above), we keep only those loans between 50 percent and 250 percent of the jumbo-mortgage cutoff, which reduces the sample to about 8.6 million applications. We then take this sample of loans and merge the observation to the Bank Call Report. This merge leaves us with a final sample of 6,143,057 loan applications.

Since we are only using about three percent of all mortgage applications, one might legitimately question the generality of the results. To address this concern, we report the frequency distribution and acceptance rates for mortgages between 50 percent and 250 percent of the jumbo-loan cutoff for both our sample, and for the full sample of applications in HMDA. As shown in Figure 5, both the frequency and acceptance rates look very similar for the two samples, suggesting that our data filters have not created a biased or unusual selection of 
mortgage applications. For example, we see in both samples a similar large upward spike in the number of applications and a jump in the acceptance rate just below the jumbo-loan cutoff. We also see the same fall off in the acceptance rate as the size of the mortgages falls, and as mortgage size increases beyond the cutoff.

Table 2 contains simple summary statistics for the mortgage application data that we use in our regression sample, and for selected years between 1992 and 2003 . We report the acceptance rate, loan size, applicant income, and the share of loans made in urban areas (i.e. in MSAs). Of the six million applications, about 91 percent are accepted. The average loan size is $\$ 209$ thousand, and the mean ratio of loan size to applicant income is 2.4. About 14 percent of the loan applicants are to minority borrowers, and about 15 percent are to female borrowers. In terms of neighborhood attributes, 92 percent of the loan applications are for properties located in MSAs. The median census tract income (averaged across tracts) is $\$ 51$ thousand per year. ${ }^{14}$ Table 2 also shows that most of these characteristics are quite stable over time, although the jumbo-loan cutoff increases as housing prices have risen throughout the sample.

Table 3 reports summary statistics for the potential-lender (bank) characteristics included in our sample (Panel A). We also report these characteristics for those banks that are excluded from our tests, either because they did not appear in the HMDA dataset, or because we were unable to match their identifier to HMDA (Panel B). The median bank in our sample holds about $\$ 85$ million in assets, and the median bank received 16 mortgage applications (15 accepted) in a typical year in the sample. This number of applications may appear small, but note that the median bank is small, and that we only consider loans near the jumbo-loan cutoff. In fact, 88 percent of loan applications are smaller than 50 percent of the jumbo-loan cutoff. The median deposit cost, defined as interest expenses on deposits divided by total deposits, equals 
about 3.3 percent, and the median bank held about 28 percent of its assets in either cash or other marketable securities. Our measure of loan liquidity, which again takes account of both a bank's portfolio choices and the depth of the market for securitization in aggregate, was about 23 percent. This variable trends upward throughout our sample period as the securitization market has expanded. In contrast, the banks excluded tend to be smaller, less focused on lending, and less focused on mortgage lending in particular, although no less profitable. This is reasonable to expect since the HMDA data cover mortgage lenders with total assets in excess of $\$ 30$ million.

\section{EMPIRICAL STRATEGY}

\section{A. Identification}

The fundamental question that we ask here is: how do funding conditions and liquidity affect an individual bank's willingness to supply credit? Answering the question convincingly creates the challenge of separating the effects of loan demand from those of loan supply. To understand this identification problem, consider the correlation between loan growth and a bank's cost of raising deposits. If availability of local deposits affects loan supply, then an increase in a bank's cost of deposits ought to be associated with a decline in loan growth. Strong loan demand, however, will tend to increase a bank's appetite for deposits to fund that demand, thus potentially leading to higher yields on deposits (and thus a positive correlation between deposit yields and loan growth). Similarly, a bank's willingness to hold liquid assets - for example, cash or other marketable securities - may be directly affected by loan demand. Where loan demand is weak, we would expect banks to hold more securities. Thus, demand-side forces will tend to generate a negative correlation between measures of bank liquidity and loan growth. 
Our research method is designed specifically to address these identification problems. The first advantage of our approach is that we focus on the acceptance rate for mortgages, rather than originations. Demand conditions will have first-order effects on the flow of loan applications, but will not directly influence a bank's decision to accept a loan. Thus, we link a bank's funding cost (the yield on deposits) and balance-sheet liquidity (the ratio of cash plus securities to assets) to its willingness to approve mortgages, conditional on all observable dimensions of loan risk.

Modeling the acceptance rate helps but does necessarily fully resolve the identification problem. Loan demand may have indirect effects on a bank's acceptance rate by altering the credit quality of the pool of applicants. For example, when demand is very strong, the loan-tovalue ratio for the typical mortgage application may be above average (due to high housing prices relative to buyers' access to equity). Because we are not able to observe property values in our data set, this demand-driven change in the applicant pool could bias our results toward finding a negative (positive) link from deposit yields (liquidity) to a bank's acceptance rate. Rather than model the overall acceptance rate, we instead focus initially on whether the acceptance rate of jumbo mortgages - mortgages that the bank must hold and therefore fund reflects funding conditions and liquidity relative to a bank's acceptance rate for non-jumbo mortgages - those that the bank can readily sell into the secondary market. So, in our benchmark tests, we regress the differential acceptance rate, defined as a bank's average acceptance rate for non-jumbo mortgages minus its acceptance rate for jumbos, on the bank's funding costs, traditional bank balance-sheet liquidity, and bank loan liquidity measure. We assume that unobserved demand-side variables affect the acceptance rates of jumbo and non-jumbo mortgages at a given bank in the same way. The identification strategy requires a relatively 
homogenous pool of loans around jumbo-loan cutoff, so we drop all loan applications below 50 percent of the jumbo-loan cutoff and above 250 percent of the cutoff. ${ }^{15}$

\section{B. Estimation}

To understand our estimation, consider two reduced form equations relating the acceptance rates to market-level demand-side variables and to bank-level funding characteristics (supply-side variables), as follows:

$$
\begin{gathered}
A^{N J}{ }_{i, t}=\gamma^{\mathrm{NJ}}{ }_{1} \text { Balance-sheet liquidity }_{i, t-1}+\gamma^{\mathrm{NJ}}{ }_{2} \text { Deposit cost }_{i, t-1}+\gamma^{\mathrm{NJ}}{ }_{3} \text { Loan liquidity }_{i, t-1}+ \\
+\beta^{N J} \text { Borrower Risk }_{i, t}^{N J}+\text { Unobservable Demand-Side Variables } \\
\mathrm{i}, \mathrm{t}
\end{gathered}
$$

where the unit of observation in these regressions is the bank-year. Subscript $i$ indicates bank, and subscript $t$ indicates year. For each bank-year, the dependent variable equals the acceptance rate for non-jumbo mortgages $\left(A R^{N J}{ }_{i, t}=\right.$ the share of mortgage applications below the jumboloan cutoff accepted by bank $i$ in year $t)$, or the acceptance rate for jumbo mortgages $\left(A R_{i, t}^{J}\right.$, defined similarly to $A R_{i, t}^{N J}$ for jumbos). Each equation contains demand-side variables that are unobservable, as well as variables reflecting the funding and liquidity position of the potential lender. We expect that banks with more balance-sheet liquidity will be more willing to supply illiquid jumbo mortgages than banks that are liquidity constrained. In contrast, liquidity constraints should not affect a bank's willingness to supply non-jumbo mortgages because these can be converted to mortgage-backed securities (which are liquid), or they can be sold off easily 
(to one of the GSEs). For funding costs, we expect banks with high deposit costs to reduce loan supply more for illiquid jumbo mortgages than for liquid non-jumbos, again because the bank must hold and thus fund the illiquid ones (Kashyap and Stein, 2000; Campello, 2002). That is, we expect the following relationships to hold:

$$
0<=\gamma_{1}^{\mathrm{NJ}}<\gamma_{1}^{\mathrm{J}} \quad \text { and } \quad 0>=\gamma_{2}^{\mathrm{NJ}}>\gamma_{2}^{\mathrm{J}}
$$

If demand-side effects are common across equations (1a) and (1b), then they can be eliminated by subtraction, as follows:

$$
\begin{aligned}
& \text { AR }^{N J}{ }_{i, t}-\text { AR }_{i, t}^{J}=\beta_{1} \text { Balance-sheet liquidity }_{i, t-1}+\beta_{2} \text { Deposit cost }_{i, t-1}+\beta_{3} \text { Loan liquidity }_{i, t-1}+ \\
& \quad+\beta^{N J} \text { Borrower Risk }_{i, t}^{N J}-\beta^{J} \text { Borrower Risk }_{i, t}^{J}+\eta_{i, t}
\end{aligned}
$$

where $\beta_{1}=\gamma^{\mathrm{NJ}}{ }_{1}-\gamma_{1}^{\mathrm{J}}$, etc. Thus, we can remove the potentially biasing demand-side effects, but we are only able to identify the difference in the coefficients in equations (1a) and (1b). Equation (1c) represents our benchmark regression.

Balance sheet liquidity and the cost of holding deposits, our main variables of interest, are defined above. We also include loan liquidity in the regressions, which may affect the differential acceptance rate either positively or negatively. On the one hand, loan liquidity per se ought to increase a bank's willingness to make illiquid loans for the same reason that the more standard measure of balance sheet liquidity does. On the other hand, banks holding very high levels of mortgages (and hence having a relatively liquid loan portfolio), may be motivated to originate non-jumbo mortgages that can easily be removed from the balance sheet. ${ }^{16}$ The increasing depth of the securitization market (illustrated in Figure 2), which tends to increase our measure of loan liquidity over time, may also encourage banks to set a lower acceptance hurdle 
for non-jumbo relative to jumbo mortgages. Thus, we include loan liquidity as a control variable, although as it turns out the main results are not sensitive to the inclusion of this variable.

To control for risk characteristics of the pool of loans used to build the dependent variable, we include the following: the ratio of the loan size to applicant income; the log of applicant income; the share of properties located in MSAs; the percent minority in the population around the property; the median income in the area around the property; and shares of female and minority loan applicants. We construct these characteristics by averaging across all of the non-jumbo loans (Borrower Risk ${ }^{N J}{ }_{i, t}$ ) and across all of the jumbo loans (Borrower Risk ${ }_{i, t}^{J}$ ). We allow the coefficients on these risk characteristics to differ by loan type. ${ }^{17}$ In addition to loan pool characteristics, we include bank size (log of assets), a measure of leverage (the capital-asset ratio), and accounting profits (net income to assets). Because there may be additional unobserved bank effects, we cluster the error in the model by bank in constructing standard errors. $^{18}$

Changes in the stance of monetary policy could in principle be included in our model to test how aggregate funding shocks (e.g. an increase in the Fed Funds rate) affect the supply of liquid v. illiquid loans. Loutskina (2005) finds, for example, that banks with balance sheets dominated by liquid mortgages tend to be less affected by changes in monetary policy than other banks. Unfortunately, the HMDA loan application data are not 'time stamped'. All we can observe is the year in which a given application is made. Since Federal Reserve policy can change sharply over the course of a single year, we simply absorb year effects with a set of indicator variables. We also incorporate state indicator variables in all of our models. According to Passmore, et al (2005), removing state effects is important, both because of 
differences in foreclosure laws across states, and because the jumbo-mortgage market is much better developed in states with relatively high housing costs, compared to states with lowerpriced houses.

\section{Results}

\section{A. Benchmark Regressions}

Table 4 reports the benchmark results. We estimate the regression specification (1c) on the sample of bank-years in which the total number of applicants for each type (non-jumbo and jumbo) is at least three to assure that we have a reasonable estimate of the acceptance rate for each observation. Balance sheet liquidity, loan liquidity, and the cost of holding deposits, our main variables of interest, are defined above. Each of these variables comes from the fourthquarter Call Report for the year before the loan application. We use prior-year bank data to reduce any mechanical relationship between our dependent variable and the bank characteristics.

The first three specifications of Table 4 focus on balance-sheet liquidity, deposit cost, and loan liquidity individually (columns 1-3). Then, we report one specification with all three variables together (column 4). Last, we report a full specification with all three variables of interest plus the full set of control variables (column 5). All five specifications suggest that banks with more balance sheet liquidity and banks with lower cost of deposits supply more credit to the illiquid sector (non-jumbos) relative to the liquid sector (jumbos). The effects are robust across specifications. This robustness suggests that omitted risk factors, such as the loan-tovalue ratio, are not biasing our key findings.

The coefficients are not only statistically significant but also economically important. For example, if we raise the balance sheet liquidity variable from the $25^{\text {th }}$ to the $75^{\text {th }}$ percentile of 
its distribution (an increase of 17.5 percent of assets), the difference between the acceptance rate of non-jumbo mortgages and jumbo mortgages falls by 0.4 percentage points. This change represents about 6 percent of the variation in the dependent variable (based on the inter-quartile range of 6.9 percentage points). For deposits, a move from the $25^{\text {th }}$ to $75^{\text {th }}$ percentile in the distribution of yields (and increase of 1.1 percentage points) is associated with a relative increase in the acceptance rate for non-jumbo mortgages of about 0.5 percentage points. So, if we compare two banks, one with low liquidity and expensive deposits and the other flush with liquidity and cheap deposits, the first bank's acceptance rate for jumbo mortgages would be about one percentage point lower than the second.

The effect of bank size in Table 4 is also notable, and further confirms our overall findings. Log of bank assets enters the regression with a negative and statistically significant coefficient. An increase in assets from the $25^{\text {th }}$ to the $75^{\text {th }}$ percentile comes with an increase in the relative acceptance rate for jumbo mortgages of 0.6 percentage points, comparable to the magnitude of the effects of both the cost of deposits and the balance-sheet liquidity ratio. Thus, larger banks are, all else equal, more likely than smaller banks to approve jumbo mortgages relative to non-jumbo mortgages. Because there are many differences in the operating and financial policies of large and small banks, we include size mainly as a control variable. But this result may reflect in part large banks' better access to alternative sources of funds, as well as their greater ability to manage liquidity risk. For example, large banks have a greater ability to borrow in the Fed Funds market than smaller banks. ${ }^{19}$ Similarly, with better ability to borrow in capital markets, large banks are also less reliant on deposits as a marginal source of funds for their lending. 


\section{B. Endogenous Loan-Application Size}

As we noted above, loan-application size itself may be determined (or affected) by banks' ability to securitize or sell off mortgages near the jumbo-loan cutoff. This notion seems consistent with the flow of applications that spikes upward for loans just below the cutoff. We do not observe exactly how a bank might influence its applicants, although it seems likely that influence could be accomplished with carrots ('lower interest rates below the cutoff...') or sticks ('the loan will only be accepted if it comes in below the cutoff...').

To test whether the pool of loans around the jumbo-loan cutoff is endogenous to bank financial condition, we construct the share of non-jumbo loans ( 95 percent to 100 percent of the cutoff) in all applications near the cutoff (95 percent to 105 percent of the cutoff), irrespective of whether or not the loan is accepted. We then relate this measure to bank financial conditions, as follows:

Non-jumbo applications within $5 \%$ of jumbo cutoff $/$ All applications within $5 \%$ of cutoff $f_{\mathrm{i}, \mathrm{t}}=$

$=\beta_{1}$ Balance-sheet liquidity $_{i, t-1}+\beta_{2}$ Deposit cost $_{i, t-1}+\beta_{3}$ Loan liquidity $_{i, t-1}$

+ Control Variables $i, t+\varepsilon_{i, t .}$.

The dependent variable indicates the extent to which a given bank may encourage marginal applicants to apply for a mortgage just below the cutoff, as a function of the bank's funding and liquidity. If more constrained banks create more high-powered incentive for applicants to reduce their demand (e.g. with a larger jumbo/non-jumbo pricing differential), then we would expect constrained banks to receive a larger share of non-jumbo applications. Thus, we expect $\beta_{1}<0$ and $\beta_{2}>0$. We use the same set of bank and loan-pool control variables included in our model of the differential probability. As before, the unit of observation is the 
bank-year, but we now include all banks with at least one loan applications of each type around the jumbo-loan cutoff (i.e. within 5 percent). And, we continue to include state and year indicators, and to cluster the residual at the bank level in constructing standard errors.

Table 5 reports the results, with the same set of five specifications reported earlier. As before, balance sheet liquidity and funding costs are significantly related to the flow of loan applications. The applicant flow is skewed toward the relatively liquid mortgages (those below the cutoff) for banks with lower levels of balance sheet liquidity or higher cost of deposits. Banks that have less liquidity or higher deposit costs seem more likely to push applicants below the jumbo-loan cutoff. This is consistent with the notion that more liquid banks and banks with cheaper deposits are better financially positioned to originate illiquid loans and hence are less likely to affect the flow of mortgage applications. These effects across specifications are robust in the statistical sense, although the coefficient on deposit cost declines when we add the full set of control variables (column 5). In terms of the coefficient magnitudes, the effect of liquidity is notable. A move from the $25^{\text {th }}$ to the $75^{\text {th }}$ percentile in the liquid-assets distribution is associated with an increase of 1.8 percentage points in the share of jumbo loans. This increase represents a 10 percent rise relative to the mean share of jumbo-loan applications (only 18 percent of the mortgages near the jumbo-loan cutoff fall above that level).

In addition, we find that both bank size and the capital-asset ratio strongly affect the flow of applications. Larger banks receive a larger share of non-jumbo loans. And, in contrast to the relative acceptance rates, where bank capital was not significant, the share of non-jumbo loan applications declines with bank capital. Well-capitalized banks seem less likely to push borrowers below the jumbo-loan threshold, perhaps indicating their willingness to originate and hold (jumbo) mortgages. 


\section{Applicant-Pool Endogeneity and Acceptance Rates}

The strong link between the applicant flows around the jumbo-loan cutoff and bank's funding and liquidity suggests that the effects of financial conditions on acceptance rates estimated in Table 4 may be understated. As shown earlier in Figure 4, the overall differential acceptance rate is biased upward (the acceptance rate spikes up just below the cutoff). The high acceptance rate just below the cutoff probably reflects high-wealth applicants' ability to reduce their borrowing relative to applicants with less wealth. The better the quality of applicants shifting below the cutoff, the larger is the bias. The financially unconstrained banks are likely to provide the weakest pricing incentive for applicants to borrow below the cutoff, leading only the highest wealth applicants to shift. In contrast, the constrained banks are likely to provide stronger incentives, leading lower quality applicants to shift as well. Thus, the bias should be largest for the unconstrained banks. ${ }^{20}$

To test this notion, we re-estimate the differential acceptance rate regressions, dropping loan applications within 5 percent of the jumbo-loan cutoff. These results are reported in Table 6. As expected, the coefficients on the financial variables are larger in magnitude and have higher levels of statistical significance than those reported in Table $4 .^{21}$

\section{Sorting of Borrowers across Banks}

Beyond the endogeneity of applicant size, the whole distribution of loan applications across banks may shift in response to the relative pricing of non-jumbos. Funding-constrained banks presumably price jumbos at higher relative rates than unconstrained banks (remember that we are unable to observe loan prices). Sorting of borrowers across banks is facilitated by mortgage brokers and internet companies that lower the cost of search relative to potential savings from small changes in prices. To the extent that most jumbo-loan borrowers avoid 
applying to funding constrained banks at all, it will be harder to observe differences in acceptance rates because the most constrained banks may price themselves out of the jumbo market entirely. Or, said slightly differently, the most constrained banks with the highest rejection rates for jumbo loans will not be observed in our data (because they receive no applications).

To test for sorting effects, we regress the overall share of non-jumbo applications (between 50 and 250 percent of the cutoff) on the same set of financing variables, loan-pool characteristics and bank characteristics (Table 7). Since we are interested in borrower's choice of bank, we drop the marginal loan applications (those within five percent of the jumbo-loan cutoff), where the size of loan itself may be endogenous. In these specifications, we include all banks that receive at least 3 applications in the 50 to 250 percent interval. We find, again, that financially constrained banks receive a significantly lower share of jumbo-loan applications, although the coefficients are smaller in magnitude than those that we estimate for the marginal loan applicants (i.e. those near the cutoff). A move from the $25^{\text {th }}$ to the $75^{\text {th }}$ percentile in the liquid-assets distribution, for example, is associated with an increase of about 1.2 percentage points in the share of jumbo loans. So, the pool of applications shifts toward more liquid loans as the originating banks become more financially constrained.

\section{E. Separating the Financial Effects on Non-jumbo and Jumbo Mortgages}

The results so far are limited in that we have estimated how a bank's liquidity or funding costs affect its supply of jumbo mortgages relative to non-jumbo mortgages. As noted, this approach is conservative because it allows us to difference out demand-side forces that might bias the relationship between bank characteristics and loan supply. However, the cost is that we are not able to identify the direct effects of the financial variables on mortgage acceptance rates. 
To estimate a model that separates the effects of funding and liquidity on non-jumbo mortgages from its effect on jumbos, we separate the acceptance rate for jumbos and non-jumbo mortgages and relate each to the balance sheet liquidity, loan liquidity and the cost of holding deposits.

This approach essentially boils down to estimating equations (1a) and (1b) above as a system of seemingly unrelated regressions (Zellner, 1962). Thus, we now analyze two acceptance rates for each bank-year: one for the non-jumbo mortgages, and one for the jumbos. We include a jumbo-loan indicator and its interaction with bank funding and liquidity characteristics (as well as every other variable), allowing us to disentangle how bank characteristics affect the acceptance rates for both types of loans. In this expanded model, the unobservable demand-side variables are no longer differenced out, but will only (potentially) bias the direct effects of liquidity and funding costs on the acceptance rate. The approach is more comprehensive because it allows us to consider significantly more bank-years in our analysis since we do not impose a condition that a bank should have at least three loan applications in both confirming and jumbo-loan categories.

Table 8 reports these results. As before, we estimate simple specifications that focus only on the variables of greatest interest, and then we report multi-variate specifications with the full set of control variables. In Panel A, we report the results for the full sample of loans, and in Panel B we again drop applications in which loan-application size is potentially endogenous (i.e. observations that are within 5 percent of the jumbo-loan cutoff). The interaction terms of balance sheet liquidity and cost of deposits with the jumbo-loan dummy have the same interpretation as the coefficients in Table 4 and Table 6 . Even though we have dramatically increased the sample, the magnitudes of these coefficients are similar to those reported earlier. 
The coefficients suggest that neither balance sheet liquidity nor deposit yields are correlated with the acceptance rate for non-jumbo mortgages. Since banks don't need to hold these loans on their balance sheet, the acceptance rate is not affected by the bank's cost of deposits or liquidity. If a bank chooses to hold a non-jumbo mortgage, then its overall liquidity does not affect this decision because it could, at relatively low cost, remove the loan by selling it into the secondary market. In contrast, the loan liquidity measure, which again is driven in large part by the depth of the securitization market as a whole, is very strongly related to the acceptance rate for both kinds of mortgages. Moreover, its effect is greater for the non-jumbo loans. This result seems sensible because it reflects the increasing relative advantage of holding the non-jumbo loans as the depth of this market has increased over time. Finally, the results once again confirm that higher liquidity and lower costs of deposits positively affect a bank's willingness to supply illiquid loans.

\section{CONCLUSIONS}

Traditional banks originated illiquid loans and funded them with liquid deposits. As a result, a decline in deposit supply (such as one following a monetary policy tightening) reduced loan supply. Banks also needed to hold enough cash to satisfy random demands for liquidity from depositors. Securitization is changing the model of banking from one of 'originate and hold' to one of 'originate and sell', thereby mitigating the effects of both deposit supply and balance sheet liquidity on loan supply. As evidence, we show that a bank's willingness to approve jumbo mortgages (an example of illiquid loans) depends on both its cost of deposits and its holdings of liquid assets. In contrast, financial condition has no effect on acceptance rates for non-jumbo loans. Given the rapid expansion of loan securitization (as well as the growth of loan 
sales and syndication), the results suggest that access to capital is less subject to variations in the supply of local deposits to banks than in the past. The expansion of the secondary market in mortgages has also likely dampened the effects of monetary policy on real economic activity by limiting the extent of the bank lending channel. 


\section{References}

Ashcraft, Adam, 2003, "New Evidence on the Lending Channel," forthcoming at the Journal of Money, Credit and Banking.

Ashcraft, Adam, 2005, "Are Banks Really Special? New Evidence from the FDIC-Induced Failure of Healthy Banks, forthcoming at the American Economic Review.

Ambrose, Brent, Michael LaCour-Little, and Anthony Sanders, 2004, "The Effects of Conforming Loan Status on Mortgage Yield Spreads: A Loan Level Analysis," Real Estate Economics, 32, 541-569.

Becker, Bo, 2005, “Geographical Segmentation of US Capital Markets,” mimeo, April 2005.

Benmelech, Effi, Mark Garmaise and Tobias Moskowitz, 2005, "Do Liquidation Values affect Financial Contracts? Evidence from Commercial Loan Contracts and Zoning Regulation," mimeo, June 2005.

Bernanke, Ben S., 1983, "Nonmonetary Effects of the Financial Crisis in Propogation of the Great Depression," American Economic Review 73(3), 257-276.

Bernanke, Ben S. and Cara Lown, 1991, "The Credit Crunch," Brookings Papers on Economic Activity 2, 205-247.

Campello, Murillo, 2002, "Internal Capital Markets in Financial Conglomerates: Evidence from Small Bank Responses to Monetary Policy," Journal of Finance 57(6), 2773-2805.

Degryse, Hans and Steven Ongena, 2005, "Distance, Lending Relationships and Competition," Journal of Finance 60, 231-266.

Demyanyk, Yuliya, Charlotte Ostergaard and Bent E. Sorensen, 2005, "U.S. Banking Deregulation, Small Businesses, and Interstate Insurance of Personal Income,” mimeo, April 2005.

Estrella, Arturo, 2002, "Securitization and the Efficacy of Monetary Policy," Federal Reserve Bank of New York, Economic Policy Review, 1-13.

Gorton, Gary and Nicholas Souleles, 2005, "Special Purpose Vehicles and Securitization," mimeo.

Frame, W. Scott and Lawrence J. White, 2005, "Fussing and Fuming about Fannie and Freddie: How much Smoke, How much Fire?” Journal of Economic Perspectives, Spring 2005.

Greenspan, Alan, 2004, Testimony before the Committee on Banking, Housing, and Urban Affairs, U.S. Senate, February 24, 2004. 
Hubbard, R. Glenn, Kenneth Kuttner and Darius Palia, 2002, "Are There Bank Effects in Borrowers' Cost of Funds? Evidence from a Matched Sample of Borrowers and Banks," Journal of Business 75(4), 559-581.

Houston, Joel, David Marcus, and Christopher James, 1997, "Capital Market Frictions and the Role of Internal Capital Markets in Banking?” Journal of Financial Economics 46(2), 135-164.

Jayaratne, Jith and Donald P. Morgan, 2000, "Capital Market Frictions and Deposit Contraints at Banks," Journal of Money Credit and Banking.

Kashyap, Anil and Jeremy Stein, 2000, "What do a Million Observations on Banks Say about the Transmission of Monetary Policy?” American Economic Review 90(3), 407-428.

Loutskina, Elena, 2005, "Does Securitization affect Bank Lending? Evidence from Bank Responses to Funding Shocks," mimeo, March 2005.

Holmstrom, Bengt and Jean Tirole, 1997, "Financial Intermediation, Loanable Funds, and the Real Sector," Quarterly Journal of Economics 112, 663-691.

Khwaja, Asim Isaz and Atif Mian, 2005, "Tracing the Impact of Bank Liquidity Shocks," mimeo, June 2005.

Morgan, Donald P., Bertrand Rime, and Philip E. Strahan, 2004, "Bank Integration and State Business Cycles," Quarterly Journal of Economics 119, 1555-1584.

Mckenzie, Joseph A., 2002, "A Reconsideration of the Jumbo/Non-Jumbo Mortgage Rate Differential," Journal of Real Estate Finance and Economics 25(2/3), 197-213.

Paravisini, Daniel, 2004, "Constrained Banks, Constrained Borrowers: The Effects of Bank Liquidity on the Availability of Credit," MIT mimeo, November.

Passmore, Wayne, Shane M. Sherlund, and Gillian Burgess, 2005, "The Effect of Housing Government-Sponsored Enterprises on Mortgage Rates," Federal Reserve Board of Governors, working paper 2005-06.

Peek, Joe and Eric Rosengren, 2000, "Collateral Damage: Effects of the Japanese Banking Crisis on Real Activity in the United States," American Economic Review 90(1), 30-45.

Petersen, Mitchell and Raghuram G. Rajan, 1994, "The Benefits of Lending Relationships," Journal of Finance 49, 3-37.

Petersen, Mitchell and Raghuram G. Rajan, 2002, "Does Distance Still Matter? The Information Revolution in Small Business Lending," Journal of Finance 57, 2533-2570. 
Slovin, M, M. Sushka, and J. Polonchek, 1993, "The Value of Bank Durability: Borrowers as Bank Stakeholders," Journal of Finance, 247-266.

Zellner, Arnold, 1962, “An Efficient Method of Estimating Seemingly Unrelated Regressions and Tests for Aggregation Bias," Journal of the American Statistical Association 57, 348-368. 
Figure 1A: Aggregate Probability of Accepting Loans and Cost of Deposits

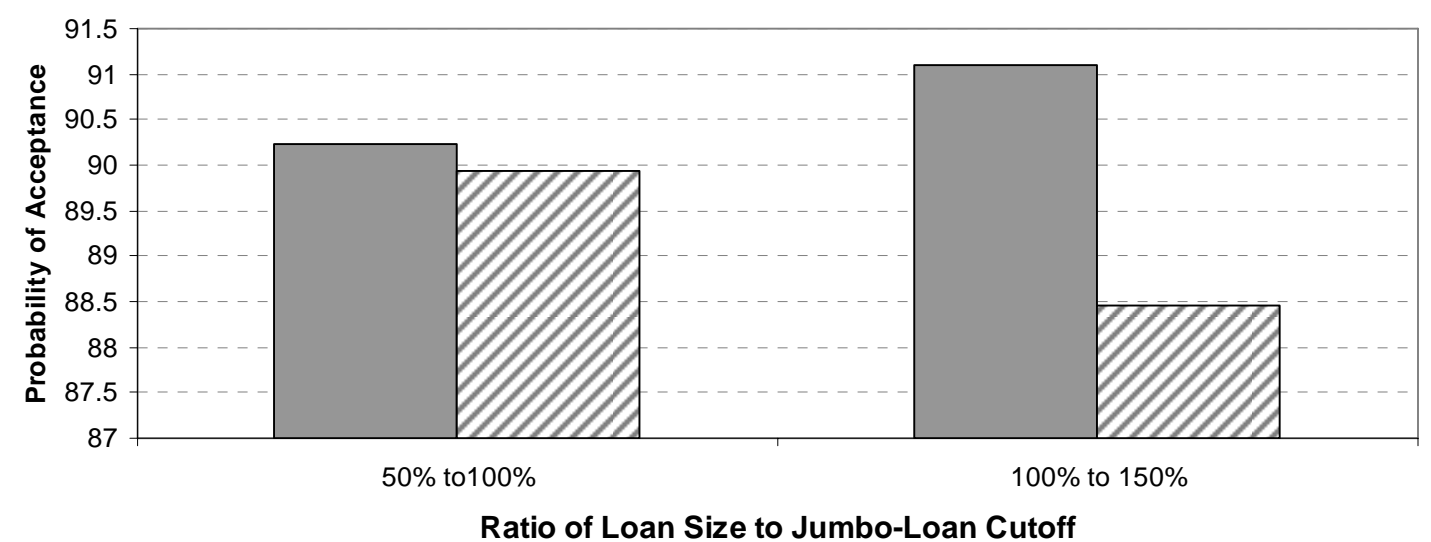

$\square$ Lowest Quartile Cost of Deposits $\quad \square$ Highest Quartile Cost of Deposits

Figure 1B: Aggregate Probability of Accepting Loans and Liquidity

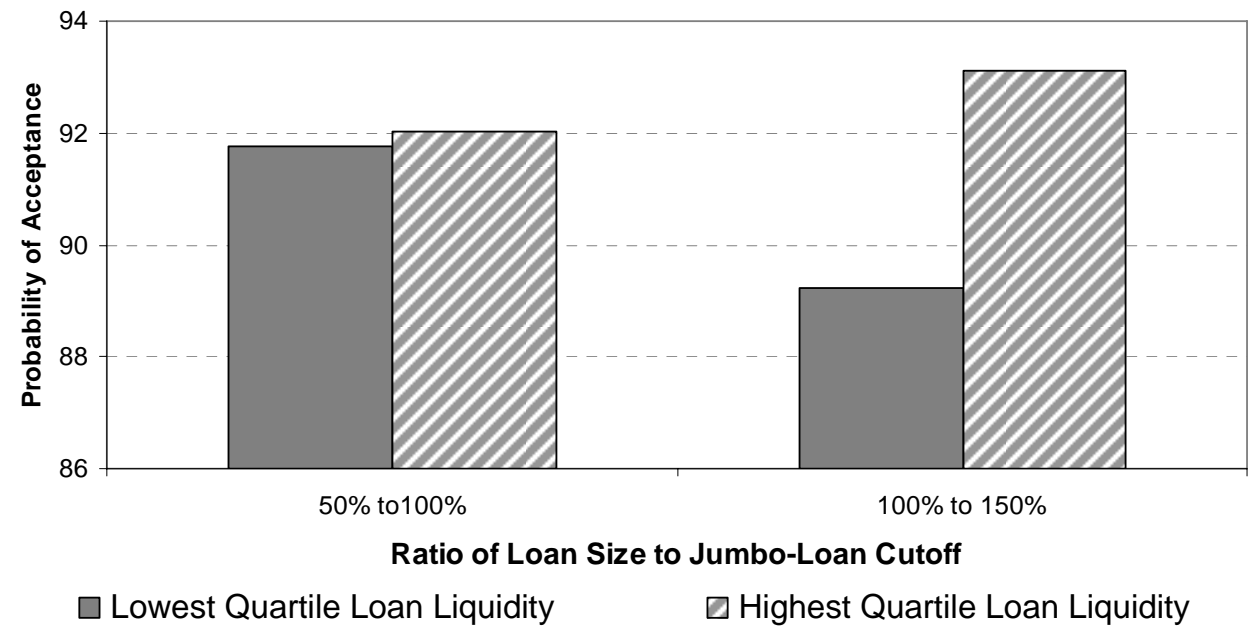

Figure 1C: Share of Non-Jumbo Loans in 95\% to 105\% Interval

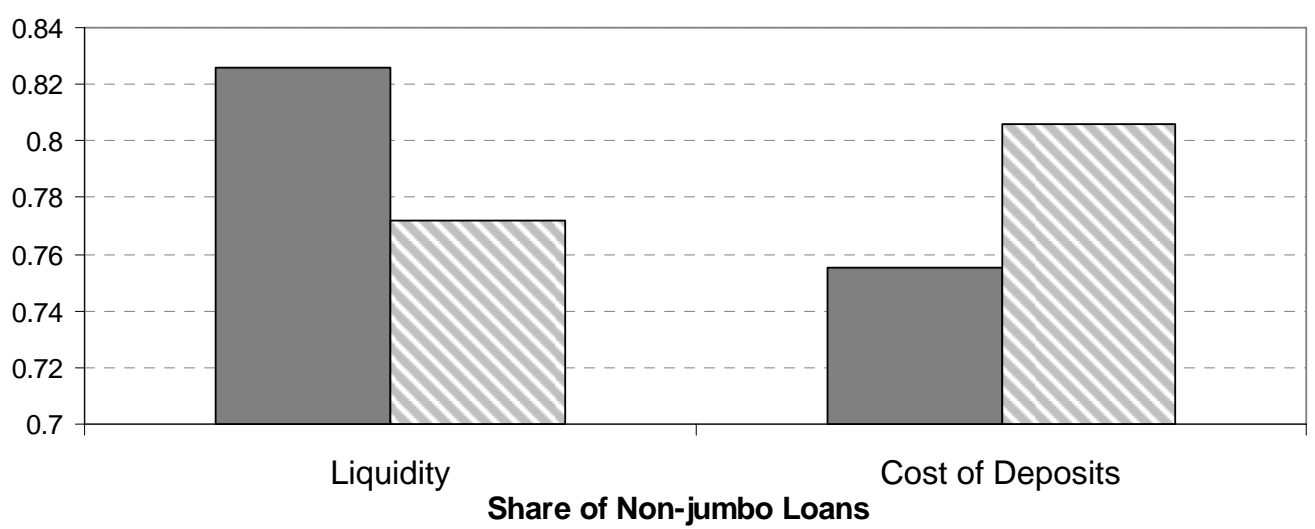

$\square$ Lowest Quartile

$\square$ Highest Quartile 
Figure 2

Securitization of Loans in the US Economy

The Figure presents the percentage of loans securitized relative to total loans outstanding for six categories of loans: (i) home mortgages, (ii) multifamily residential mortgages, (iii) commercial mortgages, (iv) consumer credit, (v) business loans, and (vi) farm mortgages. The data are from Flow of Funds Accounts of the United States.

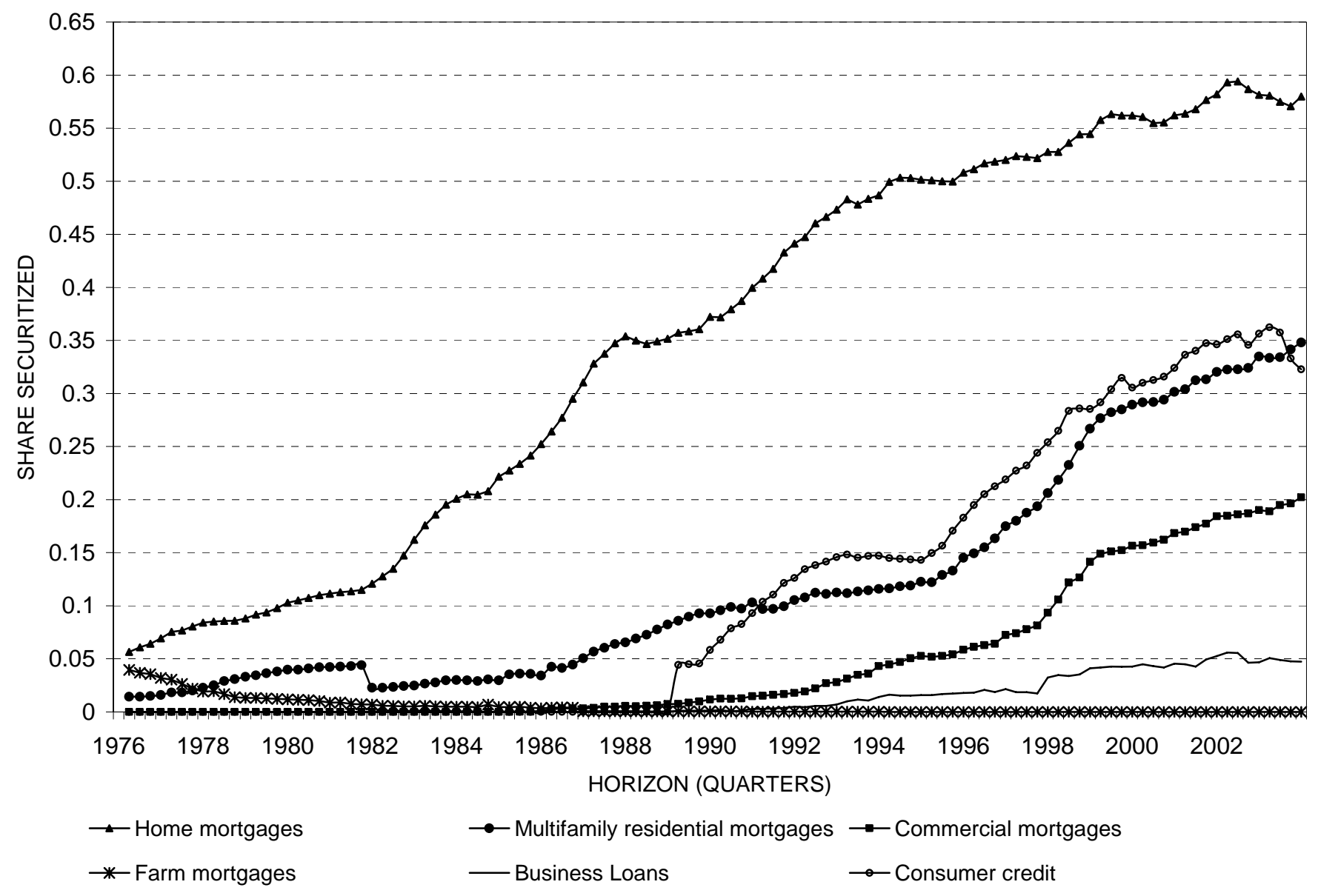


Figure 3: Jumbo/Non-Jumbo Spread Controlling for Credit Risk Source: McKenzie (2002)

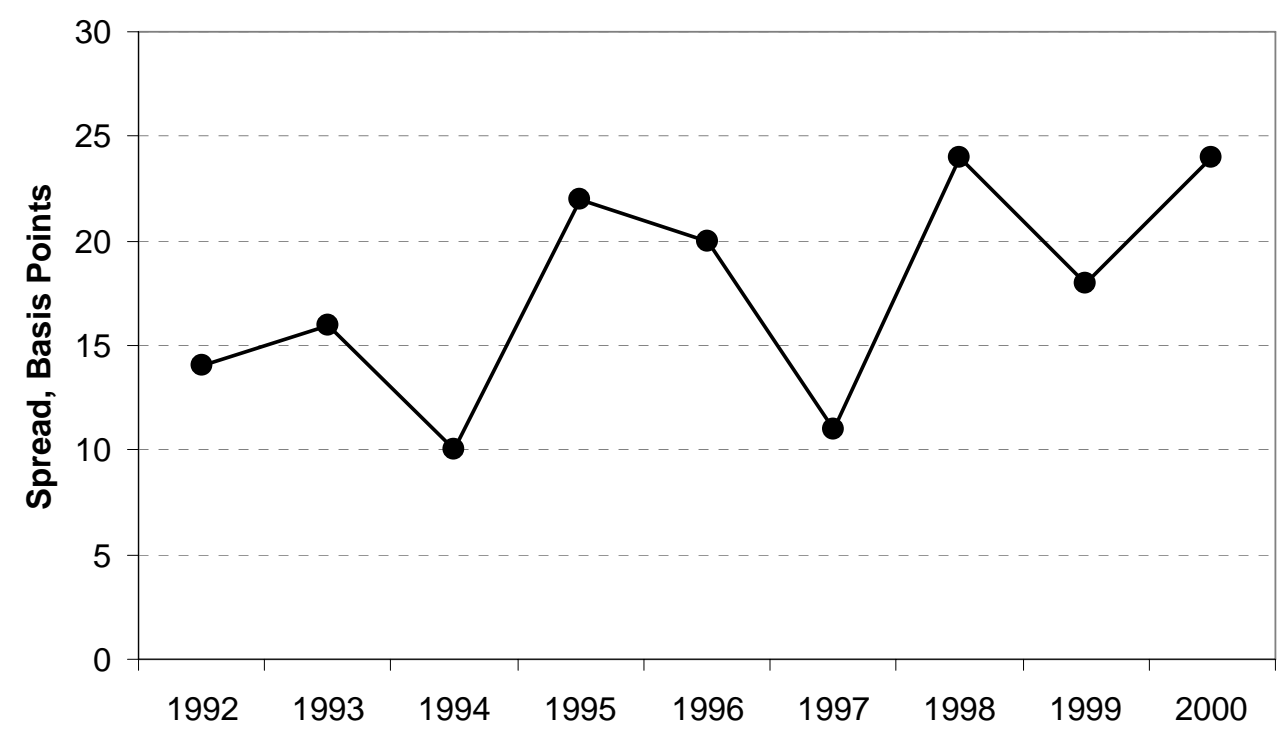


Figure 4A: Histogram of All Loan Applications, 1992-2003

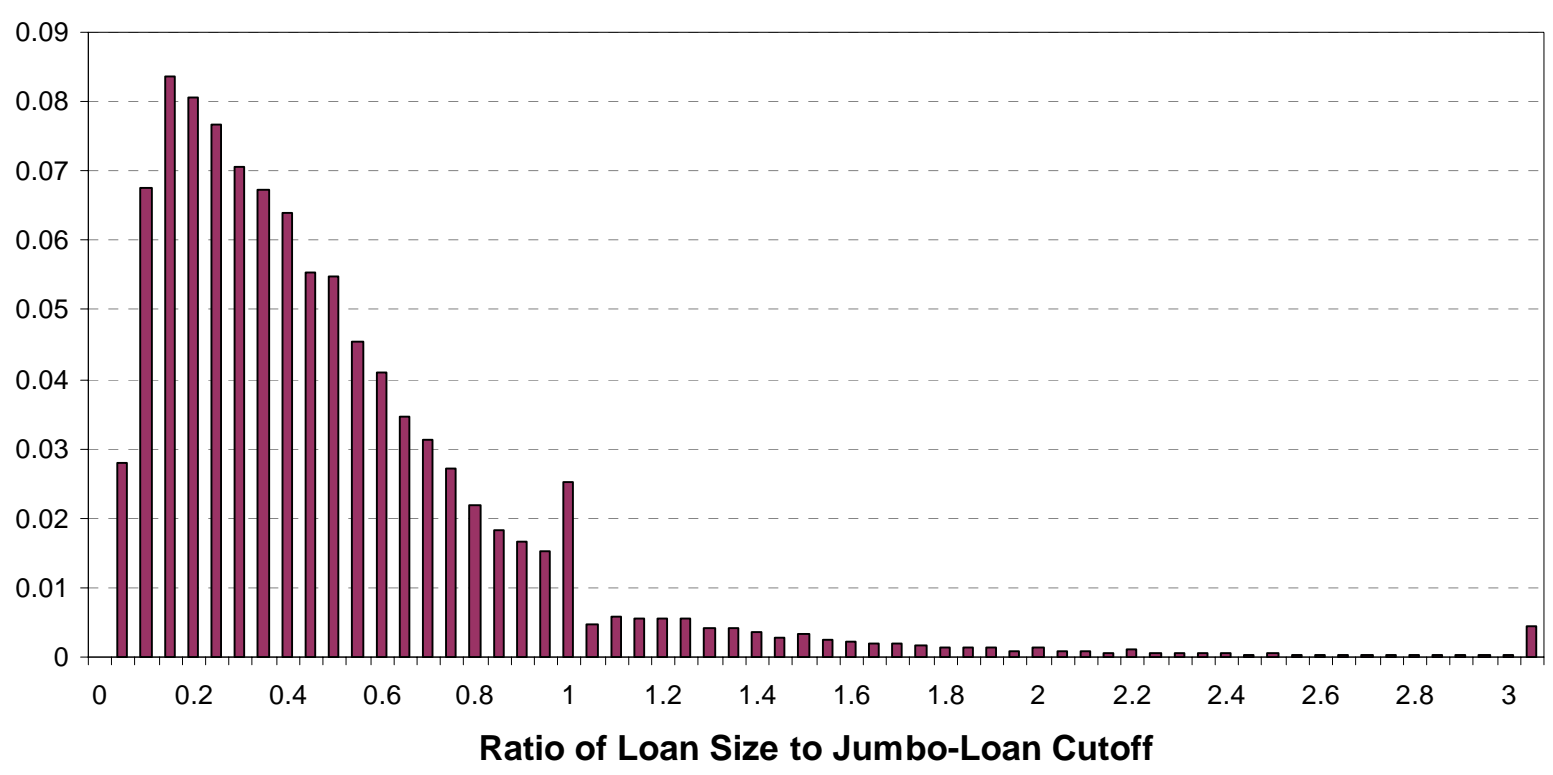

Figure 4B: Probability of Acceptance for All Loan Applications, 1992-2003

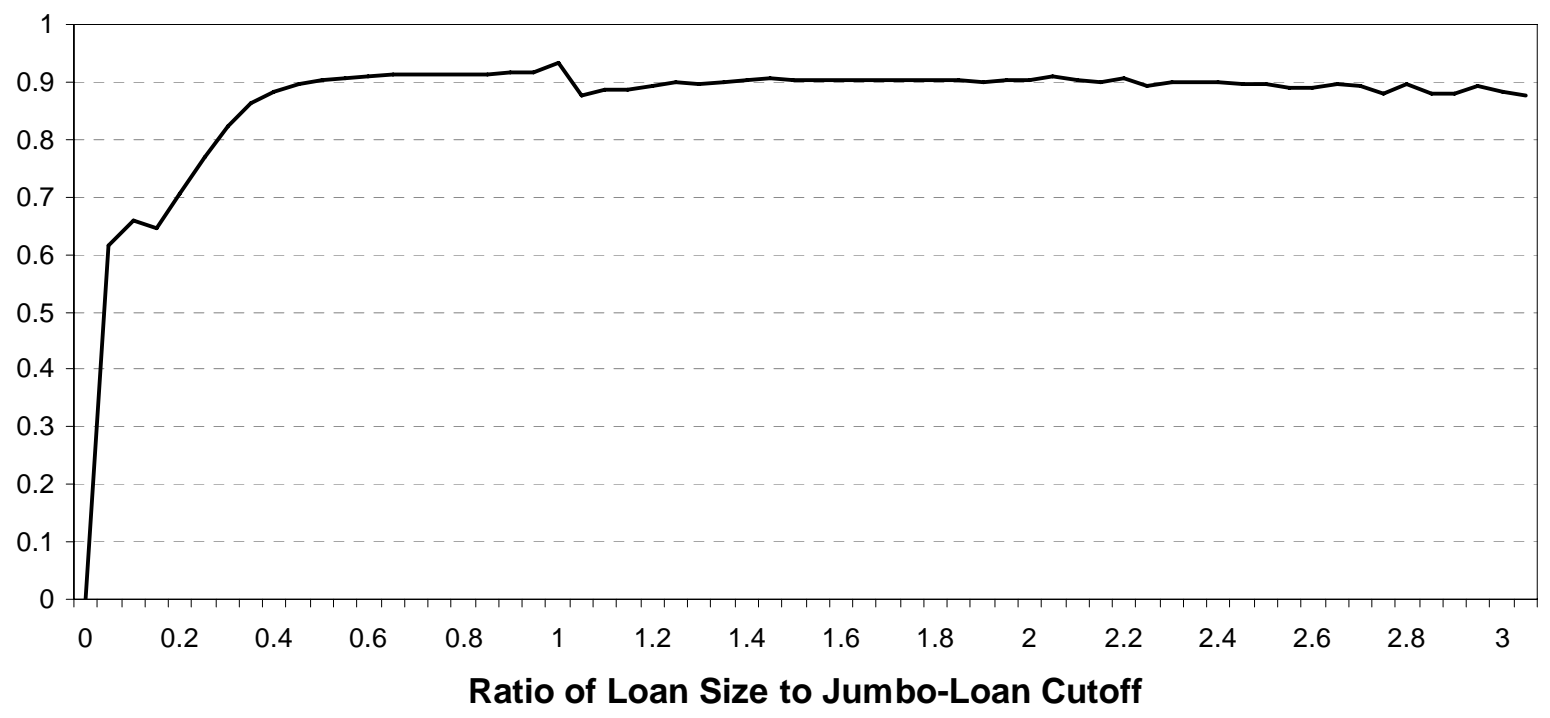


Figure 5A: Histogram of Loan Applications, 1992-2003

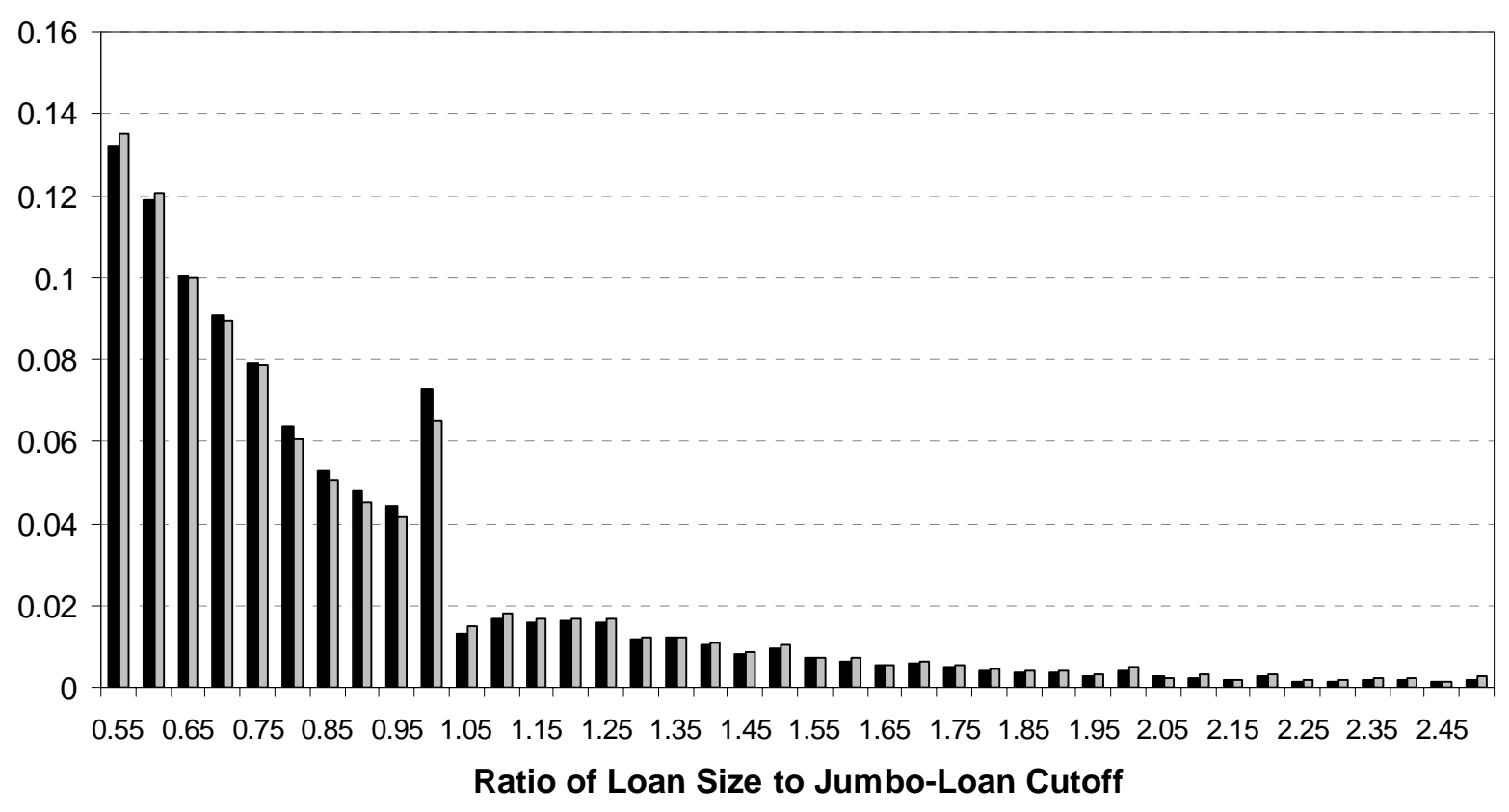

- Full Smaple $\quad \square$ Our Sample

Figure 5B: Probability of Acceptance for Loan Applications, 1992-2003

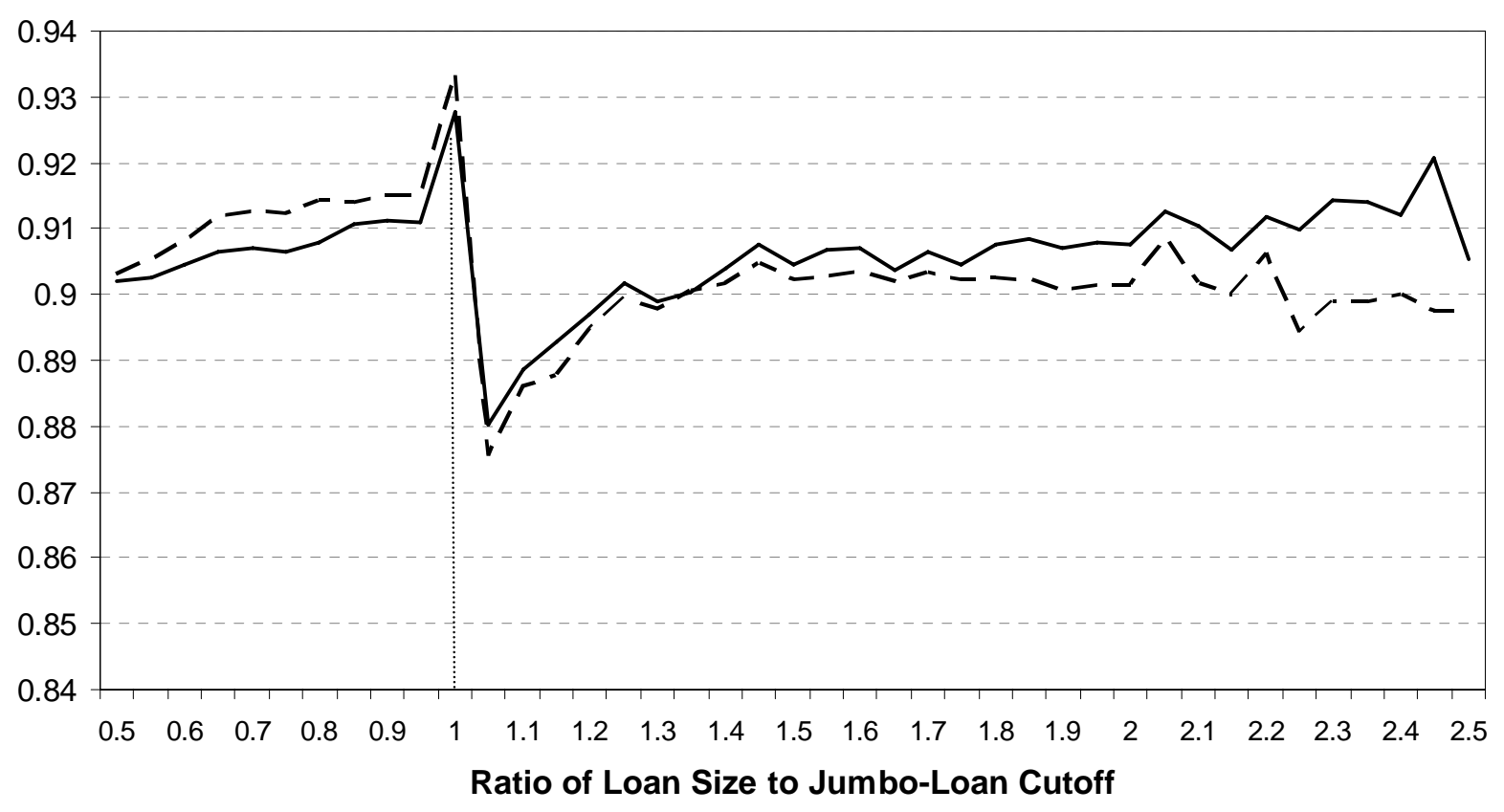

- - - Full Smaple $\quad$ Our Sample 
Single-Family Mortgages

Loans Outstanding (Billions)

Securitized Loans (Billions)

Securitized Share

Multi-Family Residential Mortgages

Loans Outstanding (Billions)

Securitized Loans (Billions)

Securitized Share

Commercial Mortgages

Loans Outstanding (Billions)

Securitized Loans (Billions)

Securitized Share

Farm Mortgages

Loans Outstanding (Billions)

Securitized Loans (Billions)

Securitized Share

Commercial \& Industrial Loans

Loans Outstanding (Billions)

Securitized Loans (Billions)

Securitized Share

Consumer Loans

Loans Outstanding (Billions)

Securitized Loans (Billions)

Securitized Share

Securitized Share

$\begin{array}{rrrr}\$ 489 & \$ 1,554 & \$ 3,533 & \$ 7,283 \\ \$ 28 & \$ 411 & \$ 1,806 & \$ 4,223 \\ 5.7 \% & 26.4 \% & 51.1 \% & 58.0 \%\end{array}$

$\begin{array}{rrrr}\$ 101 & \$ 212 & \$ 268 & \$ 504 \\ \$ 1 & \$ 9 & \$ 40 & \$ 175 \\ 1.0 \% & 4.2 \% & 14.9 \% & 34.7 \%\end{array}$

$\begin{array}{rrrr}\$ 162 & \$ 553 & \$ 729 & \$ 1,452 \\ \$ 0 & \$ 1 & \$ 45 & \$ 294 \\ 0.0 \% & 0.3 \% & 6.2 \% & 20.2 \%\end{array}$

$\begin{array}{rrrr}\$ 51 & \$ 104 & \$ 85 & \$ 132 \\ \$ 2 & \$ 0 & \$ 0 & \$ 0 \\ 3.9 \% & 0.4 \% & 0.0 \% & 0.0 \%\end{array}$

$\begin{array}{rrrr}\$ 409 & \$ 1,192 & \$ 1,674 & \$ 2,194 \\ \$ 0 & \$ 0 & \$ 30 & \$ 104 \\ 0.0 \% & 0.0 \% & 1.8 \% & 4.7 \%\end{array}$

\begin{tabular}{rrrr}
$\$ 205$ & $\$ 607$ & $\$ 1,163$ & $\$ 2,040$ \\
$\$ 0$ & $\$ 0$ & $\$ 226$ & $\$ 658$ \\
$0.0 \%$ & $0.0 \%$ & $19.4 \%$ & $32.3 \%$ \\
\hline
\end{tabular}

This table presents economy-wide loans outstanding and securitized. Data are from the U.S. Flow of Funds. 
Table 2: Summary Statistics for Mortgage Applications Characteristics

\begin{tabular}{lrrrr} 
& \multicolumn{3}{c}{ Full } & \multicolumn{2}{c}{ Selected Years: } \\
& Sample & $\underline{\mathbf{1 9 9 2}}$ & $\underline{\mathbf{1 9 9 8}}$ & $\underline{\mathbf{2 0 0 3}}$ \\
Number of Loan Applications & $6,143,057$ & 314,927 & 526,356 & 354,992 \\
Probability of Acceptance (\%) & 90.85 & 87.13 & 92.36 & 90.28 \\
Average Loan Amount (thousands) & $\$ 209$ & $\$ 174$ & $\$ 191$ & $\$ 282$ \\
Average Applicant Income (thousands / year) & $\$ 120$ & $\$ 101$ & $\$ 117$ & $\$ 142$ \\
Average Area Income (thousands / year) & $\$ 51$ & $\$ 53$ & $\$ 49$ & $\$ 70$ \\
Average Loan-to-Income Ratio & 2.4 & 2.4 & 2.3 & 2.8 \\
Percent Minority & 14.14 & 14.60 & 10.09 & 18.68 \\
Percent of Minority Population in the Area & 14.83 & 15.92 & 11.63 & 24.12 \\
Percent Female & 15.02 & 12.05 & 13.92 & 19.49 \\
Percent of Loans in MSA & 91.84 & 97.51 & 89.10 & 89.83 \\
Jumbo-Loan Cutoff (thousands) & & $\$ 202$ & $\$ 227$ & $\$ 323$ \\
\hline
\end{tabular}

This table contains summary statistics for the sample of mortgages used in the regressions reported in Tables 4-6. Figures are based on a sample of conventional home mortgage applications to commercial banks, from the HMDA data collected by the Federal Reserve Board. The mortgage applications are for loans between $50 \%$ and $250 \%$ of the jumbo-loan cutoff. The jumbo-loan cutoff is $50 \%$ higher in Alaska and Hawaii than in the other states. 
Table 3: Summary Statistics for Bank Characteristics

\begin{tabular}{|c|c|c|c|c|c|c|}
\hline & \multicolumn{3}{|c|}{ Panel A: Banks Included in Our Sample } & \multicolumn{3}{|c|}{ Panel B: Excluded Banks } \\
\hline & $\begin{array}{c}\text { 25th } \\
\text { Percentile } \\
\end{array}$ & Median & $\begin{array}{c}\text { 75th } \\
\text { Percentile } \\
\end{array}$ & $\begin{array}{c}\text { 25th } \\
\text { Percentile } \\
\end{array}$ & Median & $\begin{array}{c}\text { 75th } \\
\text { Percentile } \\
\end{array}$ \\
\hline Total Assets (millions of \$s) & 42.6 & 84.4 & 194.1 & 17.4 & 32.5 & 62.9 \\
\hline \multicolumn{7}{|l|}{ Financial Struture \& Liquidity (\%) } \\
\hline Liquid Assets / Assets & 19.9 & 27.8 & 37.4 & 22.9 & 32.7 & 43.9 \\
\hline Loan Liquidity & 16.9 & 22.8 & 30.1 & 13.1 & 19.6 & 26.8 \\
\hline Cost of Deposits & 2.7 & 3.3 & 3.9 & 2.7 & 3.5 & 4.1 \\
\hline Capital / Assets & 7.4 & 8.5 & 10.1 & 8.0 & 9.4 & 11.6 \\
\hline \multicolumn{7}{|l|}{ Loan Shares (\% of assets) } \\
\hline Total Loans & 53.9 & 63.3 & 71.1 & 47.0 & 58.1 & 67.4 \\
\hline Commercial \& Industrial Loans & 9.7 & 17.6 & 27.4 & 14.4 & 25.7 & 41.4 \\
\hline Home Mortgages & 20.2 & 31.2 & 46.3 & 14.3 & 25.2 & 37.8 \\
\hline Commercial Mortgages & 10.7 & 18.1 & 26.9 & 4.9 & 10.7 & 19.4 \\
\hline Consumer Loans & 4.9 & 9.9 & 17.5 & 7.6 & 12.8 & 20.4 \\
\hline \multicolumn{7}{|l|}{ Profit (\%) } \\
\hline Net Income / Assets & 0.7 & 1.0 & 1.3 & 0.7 & 1.1 & 1.4 \\
\hline \multicolumn{7}{|l|}{ Mortgage application } \\
\hline Number of loan applications & 6 & 16 & 54 & $\mathrm{n} / \mathrm{a}$ & $\mathrm{n} / \mathrm{a}$ & $\mathrm{n} / \mathrm{a}$ \\
\hline Number of loans Issued & 5 & 15 & 50 & $\mathrm{n} / \mathrm{a}$ & $\mathrm{n} / \mathrm{a}$ & $\mathrm{n} / \mathrm{a}$ \\
\hline Probability of Acceptance (\%) & 88.9 & 96.5 & 99.0 & $\mathrm{n} / \mathrm{a}$ & $\mathrm{n} / \mathrm{a}$ & $\mathrm{n} / \mathrm{a}$ \\
\hline
\end{tabular}

This table reports information on the distribution of characteristics for banks that we matched to the mortgage application data, and for banks that we exclude from our analysis. Liquid assets equals cash plus marketable securities. The cost of deposits equals interest expense on deposits to total deposits. Loan liquidity is a measure of the ability of a bank to sell its loans into the secondary market (see text for details). 
Table 4: Regressions Analysis of Relative Acceptance Rates for Jumbo and Non-Jumbo Mortgages

\begin{tabular}{|c|c|c|c|c|c|}
\hline Dependent Variable & $\begin{array}{l}\text { Differentia } \\
(1)\end{array}$ & $\begin{array}{c}\text { Acceptan } \\
\text { (2) }\end{array}$ & $\begin{array}{r}\text { ce Rate } \\
\text { (3) }\end{array}$ & (4) & (5) \\
\hline \multicolumn{6}{|l|}{ Bank Financial Condition } \\
\hline Liquid Assets / Assets & $\begin{array}{l}-2.65 \\
(2.88)^{* * *}\end{array}$ & & & $\begin{array}{l}-2.534 \\
(2.78)^{* * *}\end{array}$ & $\begin{array}{l}-2.345 \\
(2.58)^{* *}\end{array}$ \\
\hline Loan Liquidity & & $\begin{array}{l}4.473 \\
(3.55)^{* * *}\end{array}$ & & $\begin{array}{l}3.742 \\
(2.87)^{* * *}\end{array}$ & $\begin{array}{l}1.791 \\
(1.97)^{* *}\end{array}$ \\
\hline Cost of Deposits & & & $\begin{array}{l}57.133 \\
(3.56)^{* * *}\end{array}$ & $\begin{array}{l}43.242 \\
(2.62)^{* * *}\end{array}$ & $\begin{array}{l}42.392 \\
(2.62)^{* * *}\end{array}$ \\
\hline \multicolumn{6}{|l|}{ Other Bank Controls } \\
\hline Log of Bank Assets & & & & & $\begin{array}{l}-0.322 \\
(3.93)^{* * *}\end{array}$ \\
\hline Capital / Assets & & & & & $\begin{array}{l}0.241 \\
(0.07)\end{array}$ \\
\hline Net Income / Assets & & & & & $\begin{array}{l}-7.559 \\
(0.46)\end{array}$ \\
\hline \multicolumn{6}{|l|}{ Loan-Pool Characteristics } \\
\hline MSA share - Jumbos & & & & & $\begin{array}{l}2.27 \\
(2.17)^{* *}\end{array}$ \\
\hline MSA share - Non-Jumbos & & & & & $\begin{array}{l}-1.072 \\
(0.99)\end{array}$ \\
\hline Local area Percent Minority Population - Jumbos & & & & & $\begin{array}{l}0.043 \\
(1.67) *\end{array}$ \\
\hline Local area Percent Minority Population - Non-Jumbos & & & & & $\begin{array}{l}-0.004 \\
(0.15)\end{array}$ \\
\hline Loan-to-Income Ratio - Jumbos & & & & & $\begin{array}{l}0.488 \\
(4.74)^{* * *}\end{array}$ \\
\hline Loan-to-Income Ratio - Non-Jumbo & & & & & $\begin{array}{l}-0.502 \\
(2.21)^{* *}\end{array}$ \\
\hline Log of Applicant Income - Jumbos & & & & & $\begin{array}{l}-0.004 \\
(4.82)^{* * *}\end{array}$ \\
\hline Log of Applicant Income - Non-Jumbos & & & & & $\begin{array}{l}0.004 \\
(3.76)^{* * *}\end{array}$ \\
\hline Local area median income - Jumbos & & & & & $\begin{array}{l}-0.039 \\
(2.73)^{* * *}\end{array}$ \\
\hline Local area median income - Non-Jumbos & & & & & $\begin{array}{l}0.072 \\
(3.27)^{* * *}\end{array}$ \\
\hline Share minority applicants - Jumbos & & & & & $\begin{array}{l}5.156 \\
(4.24)^{* * *}\end{array}$ \\
\hline Share minority applicants - Non-Jumbos & & & & & $\begin{array}{l}-6.522 \\
(4.29)^{* * *}\end{array}$ \\
\hline Share Female applicants - Jumbos & & & & & $\begin{array}{l}2.693 \\
(2.40)^{* *}\end{array}$ \\
\hline Share Female applicants - Non-Jumbos & & & & & $\begin{array}{l}-0.988 \\
(0.65) \\
\end{array}$ \\
\hline Observations & 14,787 & 14,787 & 14,787 & 14,787 & 14,787 \\
\hline R-squared & 0.01 & 0.01 & 0.01 & 0.01 & 0.03 \\
\hline
\end{tabular}

T-statistics in parentheses, based on errors clustered at the bank level.

* significant at $10 \%$;* significant at $5 \%$; *** significant at $1 \%$

This table reports regressions of the acceptance rate of non-jumbo mortgages minus the acceptance rate for jumbos for bank-year observations from 1992 to 2003. Columns 1-4 report simple specifications with only bank-level financial variables; column 5 reports specifications with the full set of control variables. The acceptance rates are based on mortgages between $50 \%$ and $250 \%$ of the jumbo-loan cutoff. We only include a bank-year observation if the bank received at least 3 applications of each type. All regressions also include year and state indicators. 


\section{Table 5: Regression Analysis of the Share of Non-jumbo Mortgage Applications within $5 \%$ of the Jumbo-Loan Cutoff}

\section{Dependent Variable Non-Jumbo Applications / Total Applications}

\begin{tabular}{|c|c|c|c|c|c|}
\hline \multirow{2}{*}{\multicolumn{6}{|c|}{ Bank Financial Condition }} \\
\hline & & & & & \\
\hline Liquid Assets / Assets & $\begin{array}{l}-0.11 \\
(5.05)^{* * *}\end{array}$ & & & $\begin{array}{l}-0.111 \\
(5.09)^{* * *}\end{array}$ & $\begin{array}{l}-0.100 \\
(4.59)^{* * *}\end{array}$ \\
\hline Loan Liquidity & & $\begin{array}{l}0.102 \\
(3.16)^{* * *}\end{array}$ & & $\begin{array}{l}0.072 \\
(2.21)^{* *}\end{array}$ & $\begin{array}{l}0.076 \\
(2.34)^{* *}\end{array}$ \\
\hline Cost of Deposits & & & $\begin{array}{l}1.158 \\
(3.49)^{* * * *}\end{array}$ & $\begin{array}{l}1.012 \\
(3.05)^{* * *}\end{array}$ & $\begin{array}{l}0.628 \\
(1.95)^{*}\end{array}$ \\
\hline \multicolumn{6}{|l|}{ Other Bank Controls } \\
\hline Log of Bank Assets & & & & & $\begin{array}{l}0.025 \\
(13.36)^{* * *}\end{array}$ \\
\hline Capital / Assets & & & & & $\begin{array}{l}-0.35 \\
(3.87)^{* * *}\end{array}$ \\
\hline Net Income / Assets & & & & & $\begin{array}{l}-0.23 \\
(0.64)\end{array}$ \\
\hline \multicolumn{6}{|l|}{ Loan-Pool Characteristics } \\
\hline MSA share & & & & & $\begin{array}{l}-0.097 \\
(4.85)^{* * *}\end{array}$ \\
\hline Local area Percent Minority Population & & & & & $\begin{array}{l}0.001 \\
(0.38)\end{array}$ \\
\hline Loan-to-Income Ratio & & & & & $\begin{array}{l}-0.005 \\
(0.73)\end{array}$ \\
\hline Log of Applicant Income & & & & & $\begin{array}{l}-0.003 \\
(1.47)\end{array}$ \\
\hline Local area median income & & & & & $\begin{array}{l}0.107 \\
(10.13)^{* * *}\end{array}$ \\
\hline Share minority applicants & & & & & $\begin{array}{l}-0.017 \\
(1.01)\end{array}$ \\
\hline Share Female applicants & & & & & $\begin{array}{l}-0.019 \\
(1.24)\end{array}$ \\
\hline Observations & 7,303 & 7,303 & 7,303 & 7,303 & 7,158 \\
\hline R-squared & 0.09 & 0.08 & 0.08 & 0.09 & 0.18 \\
\hline
\end{tabular}

T-statistics in parentheses, based on errors clustered at the bank level.

* significant at $10 \%$; ** significant at $5 \%$; *** significant at $1 \%$

I his table reports regressions of the share of non-jumbo mortgages applications within $5 \%$ of the jumbo-loan cutott tor bank-year observations from 1992 to 2003. Columns 1-4 report simple specifications with only bank-level financial variables; column 5 reports specifications with the full set of control variables. We only include a bank-year observation if the bank received at least one applications of each type. All regressions also include year and state indicators. 
Table 6: Regression Analysis of Relative Acceptance Rates for Jumbo and Non-Jumbo Mortgages Without Mortgages within 5\% of Jumbo-Loan Cutoff

\begin{tabular}{|c|c|c|c|c|c|}
\hline Dependent Variable & $\begin{array}{c}\text { Differential } \\
(1)\end{array}$ & $\begin{array}{c}\text { Acceptance } \\
\text { (2) }\end{array}$ & $\begin{array}{l}\text { Rate } \\
\text { (3) }\end{array}$ & (4) & (5) \\
\hline \multicolumn{6}{|l|}{ Bank Financial Condition } \\
\hline Liquid Assets / Assets & $\begin{array}{l}-3.104 \\
(3.22)^{* * *}\end{array}$ & & & $\begin{array}{l}-2.974 \\
(3.12)^{* * *}\end{array}$ & $\begin{array}{l}-2.886 \\
(3.00)^{* * *}\end{array}$ \\
\hline Loan Liquidity & & $\begin{array}{l}4.805 \\
(3.70)^{* * *}\end{array}$ & & $\begin{array}{l}3.95 \\
(2.93)^{* * *}\end{array}$ & $\begin{array}{l}1.574 \\
(2.01)^{* *}\end{array}$ \\
\hline Cost of Deposits & & & $\begin{array}{l}65.737 \\
(3.97)^{* * *}\end{array}$ & $\begin{array}{l}51.134 \\
(2.99)^{* * *}\end{array}$ & $\begin{array}{l}49.654 \\
(2.95)^{* * *}\end{array}$ \\
\hline \multicolumn{6}{|l|}{ Other Bank Controls } \\
\hline Log of Bank Assets & & & & & $\begin{array}{l}-0.306 \\
(3.54)^{* * *}\end{array}$ \\
\hline Capital / Assets & & & & & $\begin{array}{l}0.116 \\
(0.03)\end{array}$ \\
\hline Net Income / Assets & & & & & $\begin{array}{l}-6.937 \\
(0.42)\end{array}$ \\
\hline \multicolumn{6}{|l|}{ Loan Pool Characteristics } \\
\hline MSA share - Jumbos & & & & & $\begin{array}{l}-1.45 \\
(1.23)\end{array}$ \\
\hline MSA share - Non-Jumbos & & & & & $\begin{array}{l}0.736 \\
(0.60)\end{array}$ \\
\hline Local area Percent Minority Population - Jumbos & & & & & $\begin{array}{l}-0.019 \\
(0.69)\end{array}$ \\
\hline Local area Percent Minority Population - Non-Jumbos & & & & & $\begin{array}{l}0.053 \\
(1.87)^{*}\end{array}$ \\
\hline Loan-to-Income Ratio - Jumbos & & & & & $\begin{array}{l}0.444 \\
(4.51)^{* * *}\end{array}$ \\
\hline Loan-to-Income Ratio - Non-Jumbo & & & & & $\begin{array}{l}-0.647 \\
(4.14)^{* * *}\end{array}$ \\
\hline Log of Applicant Income - Jumbos & & & & & $\begin{array}{l}-0.005 \\
(5.22)^{* * *}\end{array}$ \\
\hline Log of Applicant Income - Non-Jumbos & & & & & $\begin{array}{l}0.004 \\
(3.80)^{* * *}\end{array}$ \\
\hline Local area median income - Jumbos & & & & & $\begin{array}{l}-0.098 \\
(6.79)^{* * *}\end{array}$ \\
\hline Local area median income - Non-Jumbos & & & & & $\begin{array}{l}0.136 \\
(5.87)^{* * *}\end{array}$ \\
\hline Share minority applicants - Jumbos & & & & & $\begin{array}{l}5.515 \\
(4.42)^{* * *}\end{array}$ \\
\hline Share minority applicants - Non-Jumbos & & & & & $\begin{array}{l}-6.603 \\
(4.08)^{* * *}\end{array}$ \\
\hline Share Female applicants - Jumbos & & & & & $\begin{array}{l}2.817 \\
(2.47)^{* *}\end{array}$ \\
\hline Share Female applicants - Non-Jumbos & & & & & $\begin{array}{l}-0.71 \\
(0.46) \\
\end{array}$ \\
\hline Observations & 14,428 & 14,428 & 14,428 & 14,428 & 14,137 \\
\hline R-squared & 0.01 & 0.01 & 0.01 & 0.01 & 0.04 \\
\hline
\end{tabular}

T-statistics in parentheses, based on errors clustered at the bank level.

* significant at $10 \%$;* significant at $5 \%$; *** significant at $1 \%$

This table reports regressions of the acceptance rate of non-jumbo mortgages minus the acceptance rate for jumbos for bank year observations from 1992 to 2003. Columns 1-4 report simple specifications with only bank-level financial variables; column 5 reports specifications with the full set of control variables. The acceptance rates are based on mortgages between $50 \%$ and $250 \%$ of the jumbo-loan cutoff, without mortgages within $5 \%$ of the cutoff. We only include a bank-year observatior if the bank received at least 3 applications of each type. All regressions also include year and state indicators. 
Table 7: Regression Analysis of the Share of Non-jumbo Mortgage Applications $50 \%-95 \%$ and $105 \%-250 \%$ of Jumbo-Loan Cutoff

\begin{tabular}{|c|c|c|c|c|c|c|}
\hline & Dependent Variable & $\begin{array}{c}\text { Non-Jumb } \\
\text { (1) }\end{array}$ & $\begin{array}{c}\text { o Applicatio } \\
\text { (2) }\end{array}$ & $\begin{array}{l}\text { ns / Total A } \\
\text { (3) }\end{array}$ & $\begin{array}{l}\text { Applications } \\
\text { (4) }\end{array}$ & (5) \\
\hline \multicolumn{7}{|l|}{ Bank Financial Condition } \\
\hline Liquid Assets / Assets & & $\begin{array}{c}-0.070 \\
(4.69)^{* * *}\end{array}$ & & & $\begin{array}{c}-0.074 \\
(4.94)^{* * *}\end{array}$ & $\begin{array}{c}-0.068 \\
(5.06)^{* * *}\end{array}$ \\
\hline Loan Liquidity & & & $\begin{array}{c}0.270 \\
(11.38)^{* * *}\end{array}$ & & $\begin{array}{c}0.257 \\
(10.34)^{* * *}\end{array}$ & $\begin{array}{c}0.242 \\
(10.55)^{* * *}\end{array}$ \\
\hline Cost of Deposits & & & & $\begin{array}{c}1.790 \\
(8.42)^{* * *}\end{array}$ & $\begin{array}{c}1.084 \\
(5.01)^{* * *}\end{array}$ & $\begin{array}{c}0.564 \\
(2.92)^{* * *}\end{array}$ \\
\hline \multicolumn{7}{|l|}{ Other Bank Controls } \\
\hline Log of Bank Assets & & & & & & $\begin{array}{c}0.013 \\
(8.36)^{* * *}\end{array}$ \\
\hline Capital / Assets & & & & & & $\begin{array}{c}-0.203 \\
(3.40)^{* * *}\end{array}$ \\
\hline Net Income / Assets & & & & & & $\begin{array}{c}0.344 \\
(1.82)^{*}\end{array}$ \\
\hline Loan-Pool Characteristics & & & & - & & Included \\
\hline Observations & & $\overline{27,539}$ & 27,539 & 27,539 & 27,539 & 27,148 \\
\hline R-squared & & 0.1 & 0.12 & 0.1 & 0.12 & 0.3 \\
\hline
\end{tabular}

T-statistics in parentheses, based on errors clustered at the bank level.

* significant at $10 \%$; ** significant at $5 \%$; *** significant at $1 \%$

This table reports regressions of the share of non-jumbo mortgages applications between 50 and $250 \%$ of the jumbo-loan cutoff, exlcuding those within 5\% of the cutoff, for bank-year observations from 1992 to 2003. Columns 1-4 report simple specifications with only bank-level financial variables; column 5 reports specifications with the full set of control variables. All regressions also include year and state indicators. 
Table 8: Regression Analysis of Acceptance Rates for Jumbo and Non-jumbo Mortgages

Panel A: Loan Applications in 50 to 250\% of Jumbo-Loan Cutoff

Dependent Variable Mortgage Acceptance Rate

$(1) \quad(2) \quad(3)$

(4)

Jumbo Indicator

$\begin{array}{llll}12.54 & 14.543 & 16.046 & 16.877 \\ (4.18)^{* * *} & (4.82)^{* * *} & (5.07)^{* * *} & (5.33)^{* * *}\end{array}$

Bank Financial Condition

Liquid Assets / Assets

$-1.383 \quad$ (1.18) $\quad-1.492$

Jumbo * Liquid Assets / Assets

(1.54)

$-1.33 \quad(1.68)^{*}$

2.871

2.57

2.633

Loan Liquidity

$(2.68) * * *$

$(2.41)^{* *} \quad(2.47)^{* *}$

7.854

7.71

Jumbo * Loan Liquidity

$(5.86) * * *$

$(5.83)^{* * *}$

$-5.322$

Cost of Deposits

$(4.24)^{* * *}$

$-4.814$

Jumbo * Cost of Deposits

Other Bank Controls

Included, coefficients not reported

Conforming Loan-Pool Characteristics

Included, coefficients not reported

Jumbo Loan-Pool Characteristics

Observations

\begin{tabular}{llll}
\hline 55,994 & 55,994 & 55,994 & 55,994 \\
0.08 & 0.08 & 0.08 & 0.09 \\
\hline
\end{tabular}

R-squared

T-statistics in parentheses, based on errors clustered at the bank level.

* significant at $10 \%$; ** significant at $5 \%$; *** significant at $1 \%$

This table reports regressions of the acceptance rate of mortgages for both jumbo and non-jumbo mortgages for bank-year observations from 1992 to 2003 (i.e. there are 2 observations per bank-year). The acceptance rates are based on mortgages between $50 \%$ and $250 \%$ of the jumbo-loan cutoff. We only include a bankyear-loan observation if the bank received at least 3 applications. All regressions also include year and state indicators. We include all of the other bank \& loan-pool characteristics that appear in Tables 4-6, and we allow the coefficients to vary between the jumbo and non-jumbo acceptance rates. These coefficients are not reported here to save space. 
Table 8: Regression Analysis of Acceptance Rates for Jumbo and Non-jumbo Mortgages

\section{Panel B: Loan Applications in 50-95\% and 105-250\% of Jumbo-Loan Cutoff}

Dependent Variable Mortgage Acceptance Rate

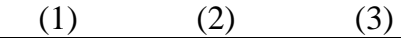

(4)

Jumbo Indicator

$\begin{array}{llll}11.148 & 13.124 & 15.764 & 16.003\end{array}$

Bank Financial Condition

Liquid Assets / Assets $(3.57)^{* * *}(4.18)^{* * *}(4.77)^{* * *}(4.85)^{* * *}$

Jumbo * Liquid Assets / Assets

$-1.369$

$-1.439$

(1.50)

2.467

2.209

$(2.24)^{* *}$

$(2.02)^{* *}$

Loan Liquidity

7.753

7.539

$(5.75)^{* * *} \quad(5.67)^{* * *}$

Jumbo * Loan Liquidity

$-5.701$

$-5.134$

Cost of Deposits

$(4.44) * * *$ (3.99)***

$41.211 \quad 25.893$

(1.59) (1.64)

Jumbo * Cost of Deposits

$-62.691-55.763$

$(4.41) * * * \quad(3.93) * * *$

Other Bank Controls

Included, coefficients not reported

Conforming Loan-Pool Characteristics

Jumbo Loan-Pool Characteristics

Included, coefficients not reported

Observations

\begin{tabular}{llll}
\hline 54,523 & 54,523 & 54,523 & 54,523 \\
0.08 & 0.08 & 0.08 & 0.09 \\
\hline
\end{tabular}

T-statistics in parentheses, based on errors clustered at the bank level.

* significant at $10 \%$; ** significant at $5 \%$; *** significant at $1 \%$

This table reports regressions of the acceptance rate of mortgages for both jumbo and non-jumbo mortgages for bank-year observations from 1992 to 2003 (i.e. there are 2 observations per bank-year). The acceptance rates are based on mortgages between $50-95 \%$ and $105-250 \%$ of the jumbo-loan cutoff. We only include a bank-year-loan observation if the bank received at least 3 applications. All regressions also include year and state indicators. We include all of the other bank \& loan-pool characteristics that appear in Tables 4-6, and we allow the coefficients to vary between the jumbo and non-jumbo acceptance rates. These coefficients are not reported here to save space. 


\section{Endnotes}

${ }^{1}$ In recent years, the GSEs have opted to hold rather than securitize many of the mortgages that they buy to take advantage of subsidized borrowing rates. Policymakers have become concerned about the resulting expansion of interest rate risk at the GSEs (Greenspan, 2004). As of 2003, for example, Fannie Mae and Freddie Mac held over $\$ 1.5$ trillion in mortgages (Frame and White, 2005). Passmore, Sherlund and Burgess (2005) argue that most (but not all) of the benefits of GSE subsidized borrowing benefits their shareholders rather than mortgage borrowers. Vickery (2005) shows that GSE subsidies are concentrated in the fixed-rate mortgage (FRM) segment rather than the adjustable-rate mortgage segment, explaining why FRMs dominate in the U.S. relative to the U.K. While the effects of this government subsidy are important for public policy, they are not the focus here.

${ }^{2}$ Benmelech, Germaise and Moskowitz (2005) use a similar identification strategy to analyze how real-asset liquidity (as opposed to financial-asset liquidity here) affects debt capacity. In their case, they exploit differences in the liquidity of commercial properties stemming from variation in zoning restrictions.

${ }^{3} \mathrm{We}$ are only able to identify which mortgages are jumbo in our data, and hence can not be sold to the GSEs. For loans below the jumbo-loan cutoff, most can be sold to the GSEs (i.e. most are 'conforming' mortgages). However, some non-jumbo loans do not meet the other criteria used to determine whether a mortgage is conforming, such as the loan-to-value ratio. Thus, there is some measurement error in our classification of loans as conforming.

${ }^{4}$ Holmstrom and Tirole (1997) present a theoretical analysis showing how real shocks can be exacerbated by reductions in credit supply. Bernanke (1983) first showed that shocks to finance can have empirically significant effects on the magnitude of business downturns, focusing on the U.S. Great Depression. More recent research has focused on regional downturns, and most studies find that such shocks are amplified by their effects on local banks (e.g. Bernanke and Lown (1991), Ashcraft (2005), Becker (2005)).

${ }^{5}$ Kashyap and Stein (2000) show that banks flush with balance-sheet liquidity respond less to monetary tightening because such banks can continue originating loans in the face of increased funding costs by running down their stock of liquid assets. Their findings complement ours, because we find that the supply of liquid loans does not respond to banks' cost of funds.

${ }^{6}$ For evidence that bank size and scope reduces the potency of monetary policy, see Ashcraft (2003), Campello (2002), Jayaratne and Morgan (2000), Kashyap and Stein (2000), and Loutskina (2005).

${ }^{7}$ Petersen and Rajan (1994) show that small firms benefit by concentrating their business with a single lender, and their results suggest that such borrowers face high costs of switching banks. Thus, many small firms are 'bank dependent'. The geographical scope of loan markets, particularly for bank dependent firms, tends to be limited geographically because local lenders have better information than competing lenders. Technology has increased the average distance between small-business borrowers and lenders, but physical proximity continues to affect bank lending supply and pricing (Petersen and Rajan, 2002; Degryse and Ongena, 2005). Our results suggest that bank dependent firms' cost of capital depends on the financial condition (cost of deposits and liquidity) of local lenders.

${ }^{8}$ Bernanke (1983) focused on credit effects of bank failures during the Depression. More recently, Bernanke and Lown (1991) show that credit in regions with many poorly capitalized banks suffered most during the 1991-92 recession. Peek and Rosengren (2000) show that distressed Japanese banks reduced credit supply to borrowers in California (relative to California banks). Ashcraft (2005) shows that local output falls when the FDIC closes even healthy banks. Slovin, Sushka and Polonchek (1993) provide evidence that borrowers from Continental Illinois were potentially harmed by that bank's failure. Hubbard, Kuttner and Palia (2002) show that low capital banks price business loans at higher yields than better-capitalized banks. Like our paper, Mian and Khwaja (2005) and Paravisini (2004) focus on how liquidity shifts loan supply. Mian and Khwaja exploit bank runs following Pakistan's unexpected nuclear test in 1998; they show that firms borrowed less from banks experiencing greater runs and more from banks experiencing smaller runs. Paravisini finds that profitable lending expands following an infusion of liquidity by the Argentine government into banks. 
${ }^{9}$ Gorton and Souleles (2005) argue that this process reduces financial distress costs of debt.

${ }^{10} \mathrm{We}$ have also disaggregated our liquidity measure by separating out mortgage-backed securities from other liquid assets. In these robustness tests, there is no additional effect of mortgage-backed securities, suggesting that our coefficient represent shifts in bank behavior in response to variation in liquidity. We thank Scott Frame for suggesting this test to us.

${ }^{11}$ See http://www.fanniemae.com.

12 The extent to which the yield differentials reflects liquidity, rather than differences in credit risk, between nonjumbo mortgages and jumbos remains somewhat controversial. A recent study by Ambrose, LaCour-Little and Sanders (2004) controls carefully for credit risk and concludes that the yield differential is only about 5 basis points between non-jumbo and jumbo mortgages. Nevertheless, there seems to be little doubt that there is an increase in yields for jumbos, and that some of that increase reflects differences in liquidity.

${ }^{13}$ Here we consider only single-family home purchase mortgage applications across the lending financial institutions in the United States.

${ }^{14}$ Note that the difference between average census tract income ( $\$ 51$ thousand) and the average applicant income ( $\$ 208$ thousand) in our sample is due to the fact that we only consider mortgages between 50 percent and 250 percent of the jumbo-loan cutoff.

${ }^{15}$ Our results are not sensitive to this assumption. For example, we have also estimated our models for loans between 75 percent and 150 percent of the jumbo-loan threshold and find similar results to those reported here. These results are available on request from the authors.

${ }^{16} \mathrm{We}$ are not able to observe the fraction of on-balance sheet mortgages that are below the jumbo-loan cutoff.

${ }^{17}$ We have also estimated a more parsimonious approach, in which we control for average bank-specific loan pool characteristics, and obtain results that are very similar to those reported here.

${ }^{18}$ We have also estimated standard errors clustered by state and clustered by year. We find similar levels of statistical significance in each of these alternative approaches to those reported here.

${ }^{19}$ Large banks typically borrow in this market, whereas smaller banks typically supply funds to the Fed Funds market.

${ }^{20}$ Note that some borrowers may split their borrowing into a non-jumbo loan plus a small subordinated second mortgage to take advantage of the jumbo/non-jumbo pricing differential. Wealthier applicants will be more able to exploit this possibility.

${ }^{21}$ The statistical significance of these results increases when we estimate the model on the logistic transformation of the non-jumbo share. 